\title{
Summertime ozone formation in Xi'an and surrounding areas, China
}

\author{
Tian Feng ${ }^{1,2,3}$, Naifang Bei ${ }^{1,2}$, Ru-Jin Huang ${ }^{2,4}$, Junji Cao ${ }^{2,3}$, Qiang Zhang ${ }^{5}$, Weijian Zhou ${ }^{3}$, Xuexi Tie ${ }^{2,3}$, \\ Suixin Liu ${ }^{2,3}$, Ting Zhang ${ }^{2,3}$, Xiaoli Su${ }^{2,3}$, Wenfang Lei ${ }^{6}$, Luisa T. Molina ${ }^{6}$, and Guohui $\mathbf{L i}^{2,3}$ \\ ${ }^{1}$ School of Human Settlements and Civil Engineering, Xi'an Jiaotong University, Xi' an, China \\ ${ }^{2}$ Key Laboratory of Aerosol Chemistry and Physics, Institute of Earth Environment, Chinese Academy of Sciences, \\ Xi'an, China \\ ${ }^{3}$ State Key Laboratory of Loess and Quaternary Geology, Institute of Earth Environment, Chinese Academy of Sciences, \\ Xi'an, China \\ ${ }^{4}$ Laboratory of Atmospheric Chemistry, Paul Scherrer Institute (PSI), Villigen, Switzerland \\ ${ }^{5}$ Department of Environmental Sciences and Engineering, Tsinghua University, Beijing, China \\ ${ }^{6}$ Molina Center for Energy and the Environment, La Jolla, CA, USA
}

Correspondence to: Guohui Li (ligh@ieecas.cn)

Received: 3 June 2015 - Published in Atmos. Chem. Phys. Discuss.: 4 November 2015

Revised: 9 March 2016 - Accepted: 13 March 2016 - Published: 7 April 2016

\begin{abstract}
In this study, the ozone $\left(\mathrm{O}_{3}\right)$ formation in China's northwest city of $\mathrm{Xi}$ ' an and surrounding areas is investigated using the Weather Research and Forecasting atmospheric chemistry (WRF-Chem) model during the period from 22 to 24 August 2013, corresponding to a heavy air pollution episode with high concentrations of $\mathrm{O}_{3}$ and $\mathrm{PM}_{2.5}$. The model generally performs well compared to measurements in simulating the surface temperature, relative humidity, and wind speed and direction, near-surface $\mathrm{O}_{3}$ and $\mathrm{PM}_{2.5}$ mass concentrations, and aerosol constituents. High aerosol concentrations in Xi' an and surrounding areas significantly decrease the photolysis frequencies and can reduce $\mathrm{O}_{3}$ concentrations by more than $50 \mathrm{\mu g} \mathrm{m}^{-3}$ (around $25 \mathrm{ppb}$ ) on average. Sensitivity studies show that the $\mathrm{O}_{3}$ production regime in Xi' an and surrounding areas is complicated, varying from $\mathrm{NO}_{x}$ to VOC (volatile organic compound)-sensitive chemistry. The industrial emissions contribute the most to the $\mathrm{O}_{3}$ concentrations compared to biogenic and other anthropogenic sources, but neither individual anthropogenic emission nor biogenic emission plays a dominant role in the $\mathrm{O}_{3}$ formation. Under high $\mathrm{O}_{3}$ and $\mathrm{PM}_{2.5}$ concentrations, a $50 \%$ reduction in all the anthropogenic emissions only decreases near-surface $\mathrm{O}_{3}$ concentrations by about $14 \%$ during daytime. The complicated $\mathrm{O}_{3}$ production regime and high aerosol levels pose a challenge for $\mathrm{O}_{3}$ control strategies in
\end{abstract}

Xi' an and surrounding areas. Further investigation regarding $\mathrm{O}_{3}$ control strategies will need to be performed, taking into consideration the rapid changes in anthropogenic emissions that are not reflected in the current emission inventories and the uncertainties in the meteorological field simulations.

\section{Introduction}

Ozone $\left(\mathrm{O}_{3}\right)$ is a key species in the atmosphere due to its role in controlling the photochemistry in the stratosphere and troposphere (Seinfeld and Pandis, 2006) since $\mathrm{O}_{3}$ and its photochemical derivative, $\mathrm{OH}$, are the major oxidants for most reduced gases (Brasseur et al., 1999). Atmospheric $\mathrm{O}_{3}$ also contributes to global climate change because of its absorption of the infrared radiation, constituting one of the important short-lived climate pollutants. Additionally, high levels of surface $\mathrm{O}_{3}$ exert deleterious impacts on ecosystems and human health (Cao et al., 2012; Zhou et al., 2011) and $\mathrm{O}_{3}$ is one of the criteria pollutants regulated by the environmental agencies in many countries, including the US Environmental Protection Agency (US EPA) and China's Ministry of Environmental Protection (China MEP).

Rapid industrialization and urbanization have caused widespread air pollution recently in China (see, e.g., De 
Smedt et al., 2010; Lu et al., 2011) and numerous studies have investigated the severe $\mathrm{O}_{3}$ pollution, particularly in the Beijing-Tianjin-Hebei (BTH) region (e.g., Wang et al. 2006; Lin et al., 2008; Tang et al., 2009; Xu et al., 2011), Yangtze River delta (YRD) region (e.g., Geng et al., 2009, 2011; Tie et al., 2009, 2012), and Pearl River delta (PRD) region (e.g., Zhang et al., 2008; Wang et al., 2009, 2011; Cheng et al., 2010; Li et al., 2013). For example, Wang et al. (2006) have observed strong $\mathrm{O}_{3}$ production in urban plumes from Beijing with a maximum $\mathrm{O}_{3}$ concentration of $286 \mathrm{ppb}$. Using a chemical transport model, Tie et al. (2009) have shown that unfavorable meteorological conditions cause high near-surface $\mathrm{O}_{3}$ levels exceeding $100 \mathrm{ppb}$ in the Shanghai region. Wang et al. (2009) have reported increasing surface $\mathrm{O}_{3}$ concentrations in the background atmosphere of southern China from 1994 to 2007.

Xi' an, located in the Guanzhong basin, is the largest city in northwestern China with a population of more than 8 million. The basin is nestled between the Qin Ling in the south and the Loess Plateau in the north with a warm-humid climate. The unique topography is not favorable for the dispersion of air pollutants (Fig. 1a) and, with fast-growing industries and urban expansion, heavy air pollution often engulfs the basin (Cao et al., 2005; Shen et al., 2008, 2009). Shen et al. (2009) reported that the $\mathrm{PM}_{2.5}$ (particulate matter with aerodynamic diameter less than $2.5 \mu \mathrm{m}$ ) mass concentrations in Xi' an exceed $350 \mu \mathrm{g} \mathrm{m}^{-3}$ during haze episodes, and straw combustion in suburban areas of $\mathrm{Xi}$ ' an increases the $\mathrm{PM}_{2.5}$ level to $400 \mathrm{\mu g} \mathrm{m}^{-3}$. However, currently studies on surface $\mathrm{O}_{3}$ measurements and formation mechanism in Xi' an are still limited. Wang et al. (2012) performed 1-year surface $\mathrm{O}_{3}$ measurement at an urban site in Xi' an in 2008 and observed high$\mathrm{O}_{3}$ episodes with $\mathrm{O}_{3}$ concentrations greater than $100 \mathrm{ppb}$ in May and June; they found that these episodes are associated with biogenic emissions from Qin Ling. Considering the increasingly stringent air quality standards in China, studies are imperative to evaluate $\mathrm{O}_{3}$ and other pollutant formation from both natural and anthropogenic emission sources to support the design and implementation of emission control strategies in the Guanzhong basin.

Since January 2013, China MEP has released the realtime hourly observations of chemical species at the national ambient monitoring stations, including $\mathrm{O}_{3}, \mathrm{NO}_{2}, \mathrm{CO}, \mathrm{SO}_{2}$, $\mathrm{PM}_{2.5}$, and $\mathrm{PM}_{10}$ (particulate matter with aerodynamic diameter less than $10 \mu \mathrm{m})$. A total of 13 national monitoring stations are distributed in the nine districts in Xi' an. In addition, continuous measurements of aerosol mass, chemical composition, and optical properties have been conducted at the Institute of Earth Environment, Chinese Academy of Sciences (IEECAS) in Xi' an since 2003. All these measurements have provided an opportunity for investigating $\mathrm{O}_{3}$ formation in Xi' an and surrounding areas. The purpose of the present study is to evaluate the $\mathrm{O}_{3}$ formation from anthropogenic and natural sources and the challenges in designing $\mathrm{O}_{3}$ control strategy due to the complicated nonlinear forma- tion of $\mathrm{O}_{3}$ and the aerosol impact on the photochemistry. The Weather Research and Forecasting atmospheric chemistry (WRF-Chem) model and the model configuration are described in Sect. 2. Results of the modeling experiments and comparisons are presented in Sect. 3, and the conclusions are given in Sect. 4.

\section{Model and method}

\subsection{WRF-Chem model}

In this study, a specific version of the WRF-Chem model (Grell et al., 2005) is applied to verify the $\mathrm{O}_{3}$ formation in Xi' an and surrounding areas; this was developed by $\mathrm{Li}$ et al. $(2010,2011 \mathrm{a}, \mathrm{b}, 2012)$ at the Molina Center for Energy and the Environment, with a new flexible gas-phase chemical module and the Community Multiscale Air Quality (CMAQ) (version 4.6) aerosol module developed by the US EPA (Binkowski and Roselle, 2003). The wet deposition follows the method used in the CMAQ module and the dry deposition of chemical species is parameterized following Wesely (1989). The photolysis rates are calculated using the Fast Tropospheric Ultraviolet and Visible Radiation Model (FTUV; Tie et al., 2003; Li et al., 2005), in which the impacts of aerosols and clouds on the photochemistry are considered (Li et al., 2011b).

We utilize ISORROPIA Version 1.7 (http://nenes. eas.gatech.edu/ISORROPIA/) to simulate the inorganic aerosols in the WRF-Chem model. The inorganic aerosol module calculates the composition and phase state of an ammonium-sulfate-nitrate-chloride-sodium-calcium-

potassium-magnesium-water inorganic aerosol in thermodynamic equilibrium with gas-phase precursors. In the present study, the module is primarily used to predict the thermodynamic equilibrium between the ammoniasulfate-nitrate-chloride-water aerosols and their gas-phase precursors of $\mathrm{H}_{2} \mathrm{SO}_{4}, \mathrm{HNO}_{3}, \mathrm{NH}_{3}, \mathrm{HCl}$, and water vapor.

The secondary organic aerosol (SOA) formation is predicted using a non-traditional SOA module. The module includes the volatility basis-set (VBS) modeling method, in which primary organic components are assumed to be semivolatile and photochemically reactive and are distributed in logarithmically spaced volatility bins (Li et al., 2011a). Nine surrogate species with saturation concentrations from $10^{-2}$ to $10^{6} \mu \mathrm{g} \mathrm{m}^{-3}$ at room temperature are used for the primary organic aerosol (POA) components following the approach of Shrivastava et al. (2008). A detailed description of the volatility basis-set approach can be found in Li et al. (2011a). The contributions of glyoxal and methylglyoxal to SOA formation are also included in the SOA module. The SOA formation from glyoxal and methylglyoxal is parameterized as a first-order irreversible uptake by aerosol particles, with a reactive uptake coefficient of $3.7 \times 10^{-3}$ for glyoxal and methylglyoxal (Zhao et al., 2006; Volkamer et al., 2007). 


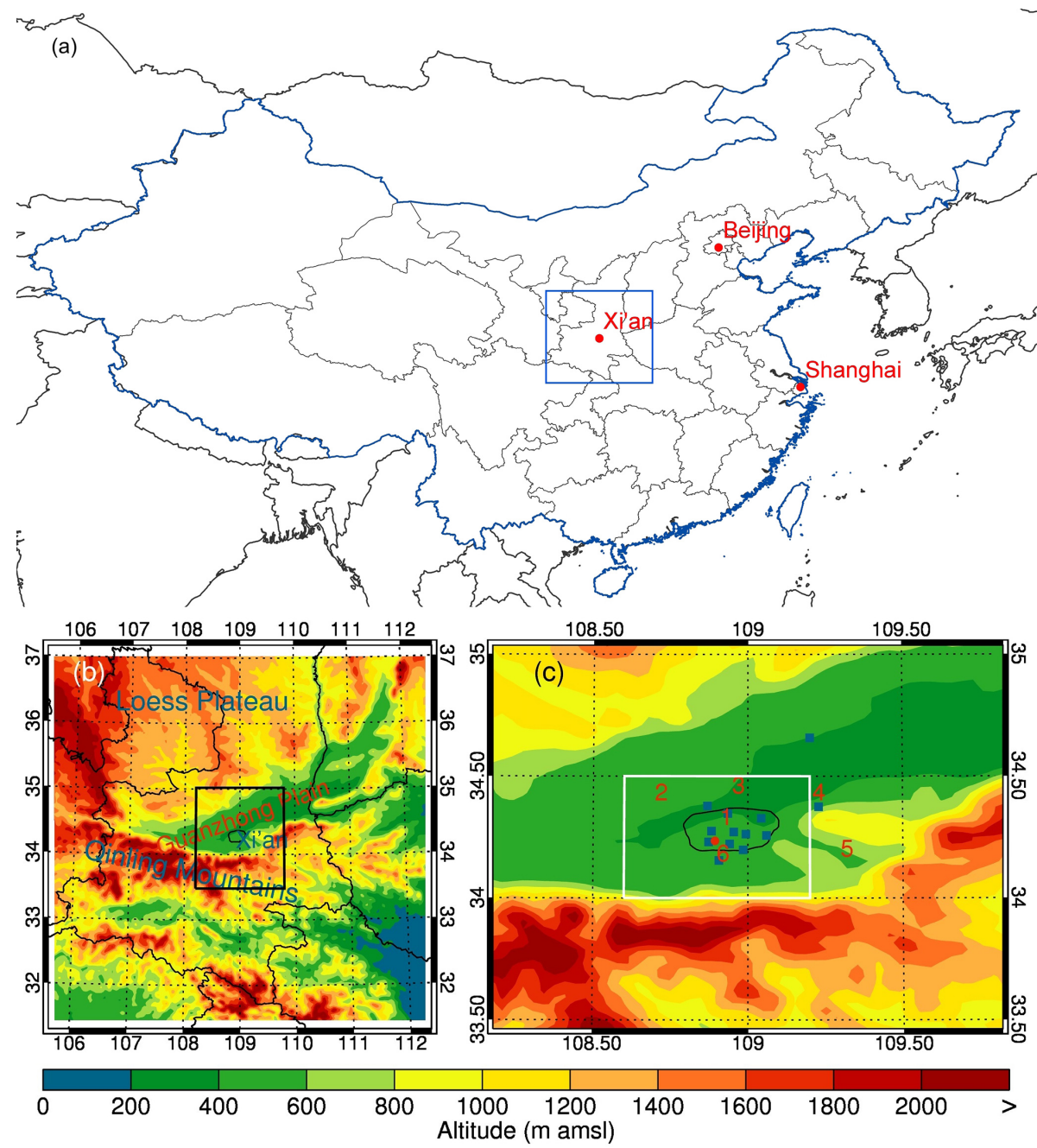

Figure 1. Map showing (a) the location of Xi' an in China, (b) WRF-Chem model simulation domain with topography, and (c) geographic distributions of surface monitoring stations. In (c), the blue squares represent the chemical species monitoring stations and the red circle is the IEECAS site. The red numbers denote meteorological observation sites. 1: Xi'an; 2: Xianyang; 3: Jinghe; 4: Lintong; 5: Chang'an; 6: Lantian. In addition, the area surrounded by the white rectangle in (c) is defined as Xi' an and surrounding areas according to the plume movement, and the area surrounded by the black line is the urban region of $\mathrm{Xi}$ ' an.

\subsection{Model configuration}

A 3-day episode from 22 to 24 August 2013 is selected for this study, representing a heavy air pollution event in Xi' an and surrounding areas with high levels of $\mathrm{O}_{3}$ and $\mathrm{PM}_{2.5}$. The WRF-Chem model is configured with grid spacing of $3 \mathrm{~km}$ $\left(201 \times 201\right.$ grid points) centered at $34.25^{\circ} \mathrm{N}$ and $109^{\circ} \mathrm{E}$ (Fig. 1a). Thirty-five vertical levels are used in a stretched vertical grid with spacing ranging from $50 \mathrm{~m}$ near the surface to $500 \mathrm{~m}$ at $2.5 \mathrm{~km}$ a.g.l. and more than $1 \mathrm{~km}$ above $14 \mathrm{~km}$. The modeling system employs the microphysics scheme of Lin et al. (1983), the Mellor, Yamada, and Janjic (MYJ) turbulent kinetic energy (TKE) planetary boundary layer scheme and the MYJ surface layer scheme (Janjic, 2002), the Unified Noah land-surface model (Chen and Dudhia, 2001), the rapid radiative transfer model (RRTM) longwave radiation parameterization (Mlawer et al., 1997), and the Goddard shortwave module (Chou and Suarez, 1994). Meteorological initial and boundary conditions are obtained from NCEP $1^{\circ} \times 1^{\circ}$ reanalysis data. Chemical initial and boundary conditions are interpolated from Model for OZone And Related chemical Tracers (MOZART) 6h output (Horowitz et al., 2003). For the episode simulations, the spin-up time of the WRF-Chem model is 1 day.

The SAPRC 99 (Statewide Air Pollution Research Center, version 1999) chemical mechanism is utilized in the simulations. The anthropogenic emission inventory (EI) used in the present study is developed by Zhang et al. (2009), which includes contributions from agriculture, industry, power generation, and residential and transportation sources (Fig. 2). 

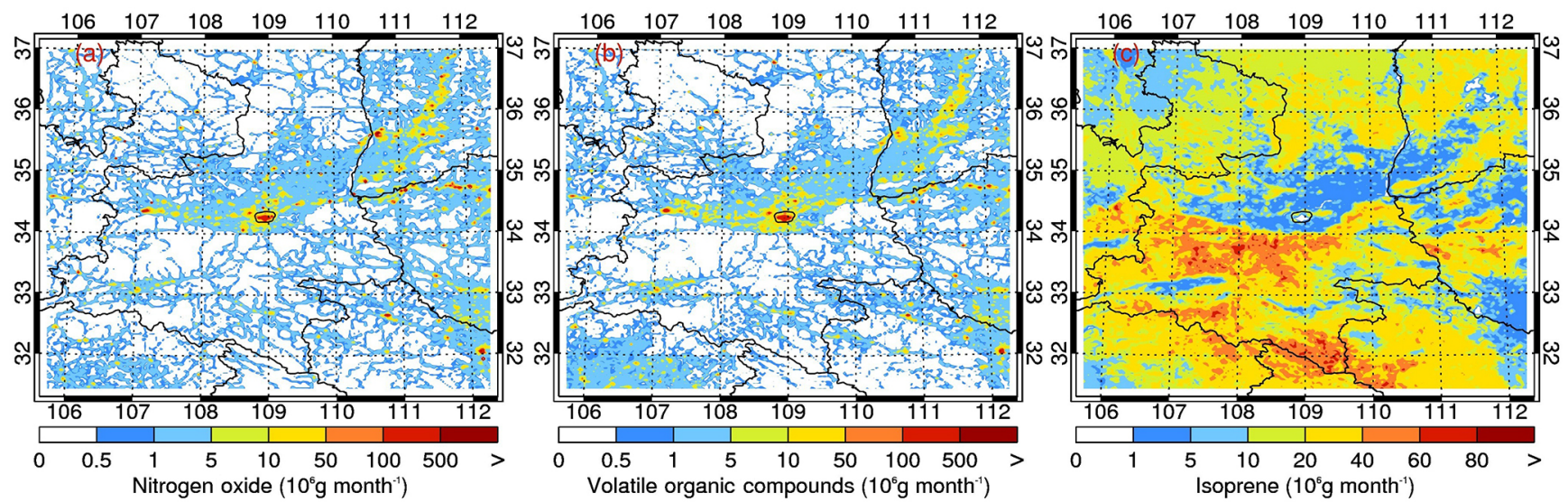

Figure 2. Geographic distributions of anthropogenic emissions of (a) nitrogen oxide, (b) volatile organic compounds, and (c) biogenic isoprene emission in the simulation domain. The black lines present provincial boundaries in China.

High emissions of volatile organic compounds (VOCs) and nitrogen oxide $\left(\mathrm{NO}_{x}\right)$ are concentrated in $\mathrm{Xi}$ 'an and surrounding areas. The primary organic aerosol emissions are redistributed following the study of Tsimpidi et al. (2010). Additionally, the biogenic emissions are calculated online with the WRF-Chem model using the Model of Emissions of Gases and Aerosol from Nature (MEGAN; Guenther et al., 2006).

\subsection{Statistical methods for comparisons}

In this study, the mean bias (MB), the root mean square error (RMSE), and the index of agreement (IOA) are used to evaluate the WRF-Chem model simulations of meteorological parameters, gas-phase species, and aerosols.

$\mathrm{MB}=\frac{1}{N} \sum_{i=1}^{N}\left(P_{i}-O_{i}\right)$

$\mathrm{RMSE}=\left[\frac{1}{N} \sum_{i=1}^{N}\left(P_{i}-O_{i}\right)^{2}\right]^{\frac{1}{2}}$,

$\mathrm{IOA}=1-\frac{\sum_{i=1}^{N}\left(P_{i}-O_{i}\right)^{2}}{\sum_{i=1}^{N}\left(\left|P_{i}-\bar{O}\right|+\left|O_{i}-\bar{O}\right|\right)^{2}}$,

where $P_{i}$ and $O_{i}$ are the simulated and observed variables, respectively. $N$ is the total number of the predictions used for comparisons, and $\bar{O}$ denotes the average of the observation. IOA ranges from 0 to 1 , with 1 indicating perfect agreement between model and observation.

\subsection{Pollutant measurements and air quality standard in China}

The real-time hourly measurements of $\mathrm{O}_{3}, \mathrm{NO}_{2}$, and $\mathrm{PM}_{2.5}$ used in this study are released by China MEP and can
Table 1. Air quality standards, individual air quality indices (IAQI), and their corresponding hourly $\mathrm{O}_{3}$ and $\mathrm{PM}_{2.5}$ concentration limits.

\begin{tabular}{lrrr}
\hline $\begin{array}{l}\text { Air quality } \\
\text { standards }\end{array}$ & IAQI & $\begin{array}{r}\text { Hourly } \mathrm{O}_{3} \\
\text { concentration } \\
\left(\mu \mathrm{g} \mathrm{m}^{-3}\right)\end{array}$ & $\begin{array}{r}\text { Hourly } \mathrm{PM}_{2.5} \\
\text { concentration } \\
\left(\mu \mathrm{g} \mathrm{m}^{-3}\right)\end{array}$ \\
\hline Excellent & 50 & 160 & 35 \\
Good & 100 & 200 & 75 \\
Lightly polluted & 150 & 300 & 115 \\
Moderately polluted & 200 & 400 & 150 \\
Heavily polluted & 300 & 800 & 250 \\
Severely polluted & $300^{+}$ & $800^{+}$ & $250^{+}$ \\
\hline
\end{tabular}

be accessed from the website http://106.37.208.233:20035/. The historical profile of the observed ambient pollutants can be accessed at http://www.aqistudy.cn/. The $\mathrm{O}_{3}, \mathrm{NO}_{2}$, and $\mathrm{PM}_{2.5}$ concentrations are measured, respectively, by using Model 49i Ozone Analyzer, Model $42 i\left(\mathrm{NO}-\mathrm{NO}_{2}-\mathrm{NO}_{x}\right)$ Analyzer, and Model 5030 SHARP Monitor from Thermo Fisher Scientific, USA. All the instruments are maintained and routinely calibrated by China MEP to ensure data quality.

The Chinese air quality standard released in 2012 is categorized into six levels based on the observed hourly and daily pollutants concentrations. During summertime, $\mathrm{O}_{3}$ and $\mathrm{PM}_{2.5}$ are the major atmospheric pollutants. A brief summary of the air quality standard based on the hourly $\mathrm{O}_{3}$ and $\mathrm{PM}_{2.5}$ concentrations is presented in Table 1 .

\section{Results and discussion}

\subsection{Summertime meteorological fields and air quality in Xi'an}

Figure 3a-d show the temporal variations of the temperature, relative humidity, and wind speed and direction at $\mathrm{Xi}-$ 

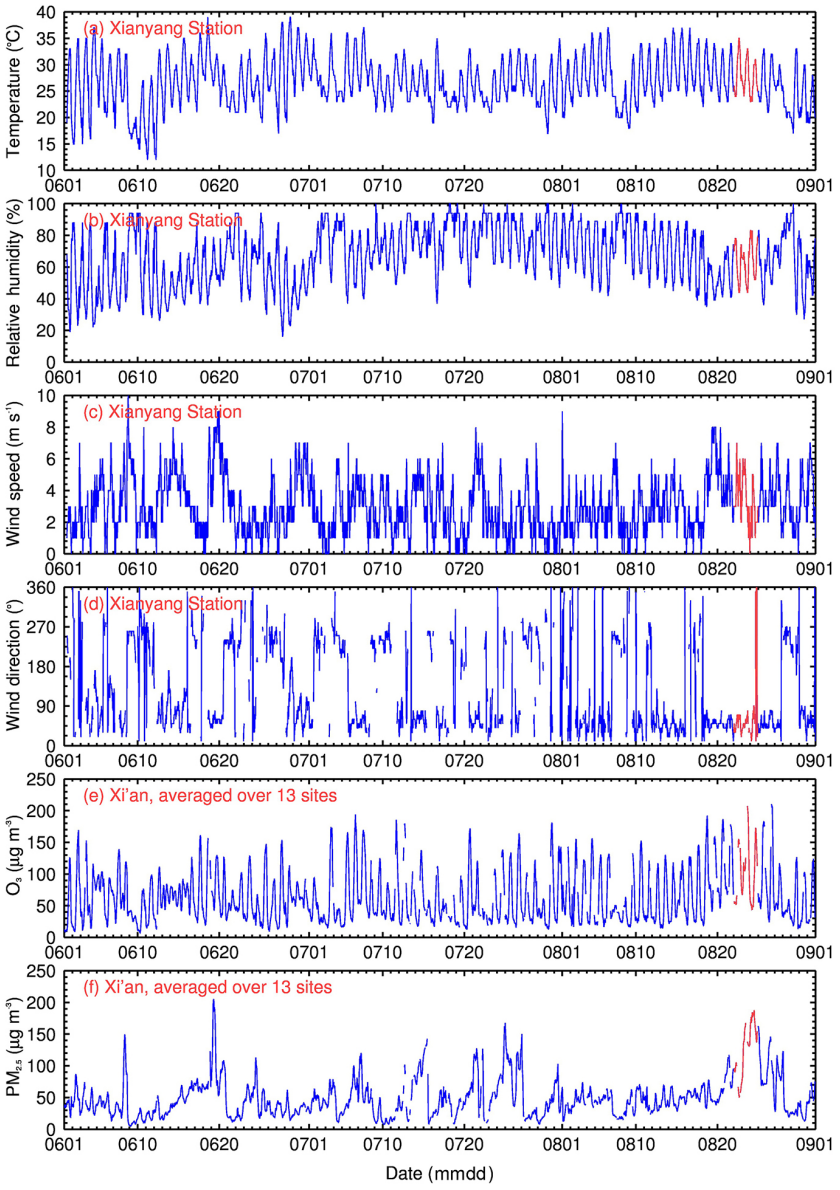

Figure 3. Temporal variations of the observed surface (a) temperature, (b) relative humidity, (c) wind speed, and (d) wind direction at Xianyang Meteorological Station and near-surface (e) $\mathrm{O}_{3}$ and (f) $\mathrm{PM}_{2.5}$ concentrations averaged over 13 sites in Xi'an during summer of 2013. Red curves depict the simulation period (22-24 August) in this study.

anyang meteorological station (Fig. 1c) during the summer of 2013. In general, the Guanzhong basin is hot and humid in the summer, with an average temperature of $26.7^{\circ} \mathrm{C}$ and a relative humidity of $67.2 \%$ recorded at the Xianyang station. The winds are not strong in the basin; the average wind speed is around $3 \mathrm{~m} \mathrm{~s}^{-1}$ at the Xianyang station. During the simulation period, the observed average temperature, relative humidity, and wind speed at Xianyang station are $27.9^{\circ} \mathrm{C}, 63.4 \%$, and $3.4 \mathrm{~m} \mathrm{~s}^{-1}$, respectively, representing typical summertime meteorological conditions.

The profiles of summertime hourly $\mathrm{O}_{3}$ and $\mathrm{PM}_{2.5}$ concentrations averaged over 13 sites in Xi' an are also shown in Fig. 3e and $\mathrm{f}$, respectively, to provide an overview of the air quality in the summer of 2013. The observed average $\mathrm{PM}_{2.5}$ and peak $\mathrm{O}_{3}$ concentrations frequently exceed 75 and $160 \mu \mathrm{g} \mathrm{m}^{-3}$, respectively, showing bad air quality in Xi'an. The simulation period corresponds to a heavy pollution episode with fairly high $\mathrm{O}_{3}$ and $\mathrm{PM}_{2.5}$ concentra-

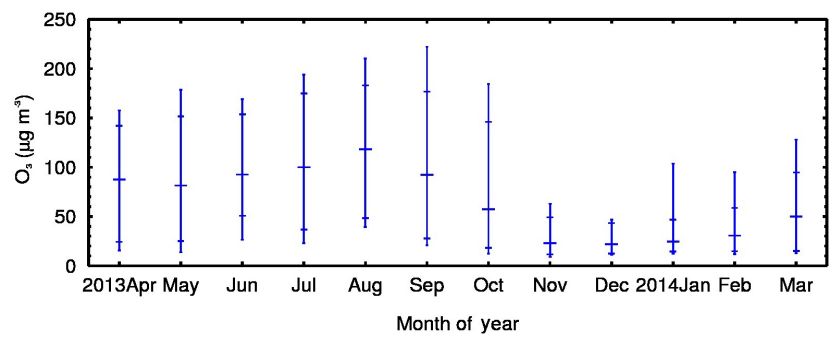

Figure 4. Monthly minimum, 5th percentile, median, 95th percentile, and maximum of near-surface $\mathrm{O}_{3}$ concentrations in the afternoon averaged over 13 observational sites in Xi'an from April 2013 to March 2014.

tions, which often occurs during summertime. Figure 4 further presents the monthly minimum, 5 th percentile, median, 95th percentile, and maximum observations of near-surface $\mathrm{O}_{3}$ concentrations in the afternoon averaged over 13 sites in Xi' an during the period from April 2013 to March 2014. The seasonal cycle of $\mathrm{O}_{3}$ levels in Xi' an shows high summertime $\mathrm{O}_{3}$ concentrations, which is consistent with the observation in the North China Plain (Cooper et al., 2014). In the study of Cooper et al. (2014), the midday $\mathrm{O}_{3}$ mixing ratio in the North China Plain peaks in June and then decreases in July and August due to the southerly monsoon flow. However, during the summer of 2013, the median $\mathrm{O}_{3}$ concentration in the afternoon in Xi' an increases progressively from about $90 \mu \mathrm{g} \mathrm{m}^{-3}$ in June to $120 \mu \mathrm{g} \mathrm{m}^{-3}$ in August, with the maximum increasing from about $170 \mu \mathrm{g} \mathrm{m}^{-3}$ in June to $210 \mu \mathrm{g} \mathrm{m}^{-3}$ in August, which is possibly caused by the inland location of $\mathrm{Xi}$ 'an with less monsoon precipitation during summertime.

Table 2 shows the comparison of summertime $\mathrm{O}_{3}$ and $\mathrm{PM}_{2.5}$ concentrations (averaged in the afternoon) in Xi' an to those in the main cities of BTH, YRD, and PRD in China during 2013. The $\mathrm{O}_{3}$ and $\mathrm{PM}_{2.5}$ concentrations in cities of $\mathrm{BTH}$ are much higher than those in $\mathrm{Xi}$ ' an, showing the heavy air pollution in BTH. Due to the impact of frequent precipitation in southern China, the $\mathrm{PM}_{2.5}$ concentrations in the cities of YRD and PRD are lower than those in Xi' an, but the $\mathrm{O}_{3}$ concentrations in Shanghai and Hangzhou are still higher than those in Xi' an. Generally, the air quality in Xi' an is better than that in the cities of BTH but worse than that in Guangzhou of PRD.

\subsection{Model performance}

For the purpose of this discussion, we have defined the reference simulation as that in which the emissions from various sources and aerosol effects on the photochemistry are included (hereafter referred to as REF), and results from the reference simulation are compared with the observations in Xi' an. 

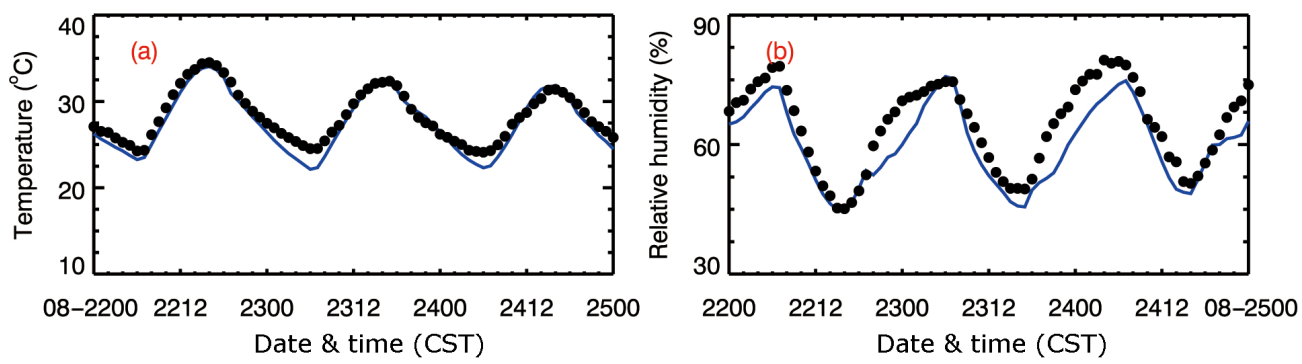

Figure 5. Observed (black dots) and simulated (blue lines) diurnal profiles of (a) surface temperature and (b) relative humidity averaged over six meteorological sites from 22 to 24 August 2013.
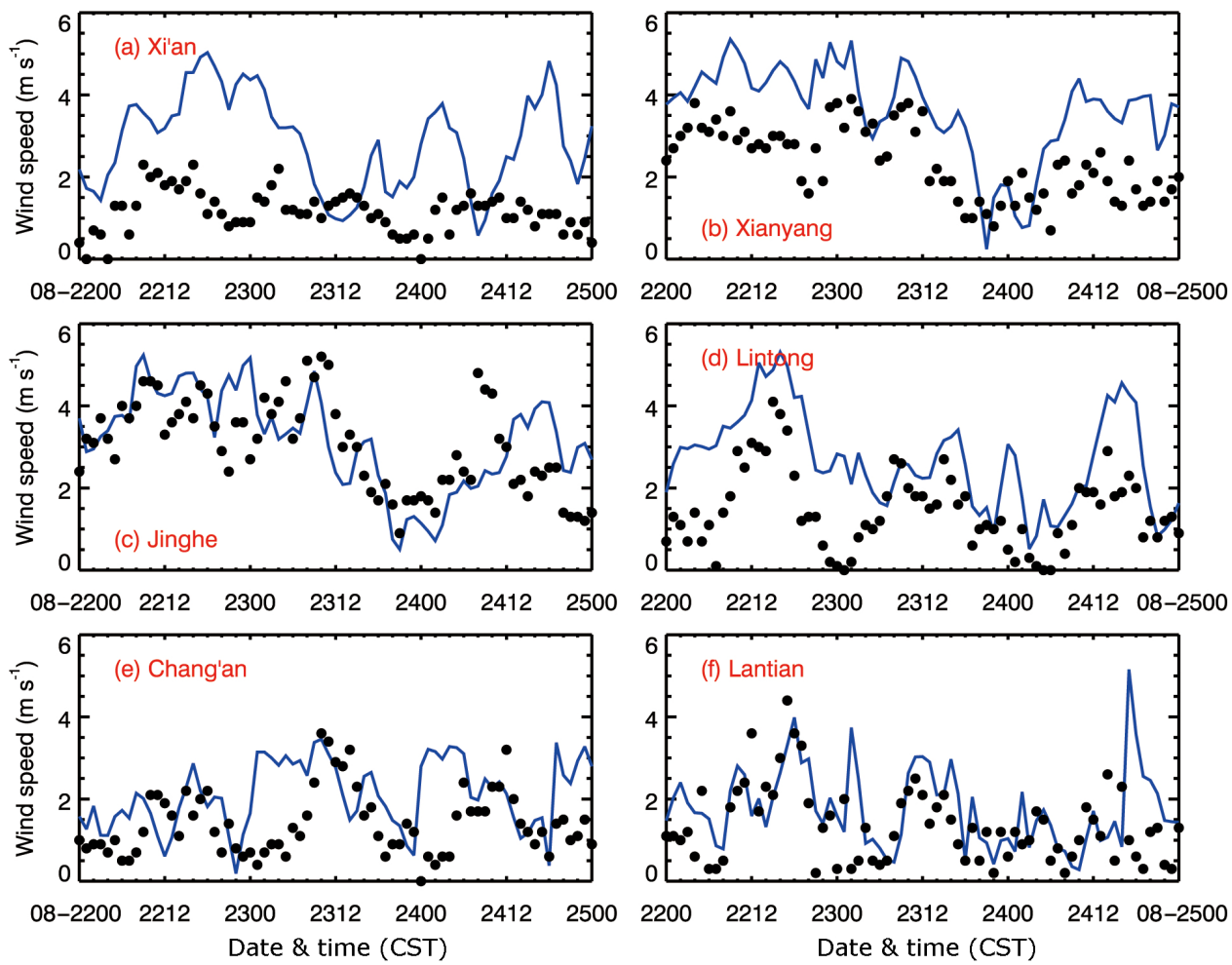

Figure 6. Observed (black dots) and simulated (blue lines) diurnal profiles of surface wind speeds at six meteorological sites from 22 to 24 August 2013.

\subsubsection{Meteorological field simulations}

Considering that the meteorological conditions play a crucial role in air pollution simulations (Bei et al., 2008, 2010, 2012), which determine the accumulation or dispersion of pollutants, verifications are first performed for the simulations of meteorological fields in Xi' an and surrounding areas. Figure 5 shows the temporal profiles of the simulated and observed surface temperature and relative humidity averaged over six meteorological observation sites from 22 to $24 \mathrm{Au}-$ gust 2013. The WRF-Chem model reproduces successfully the temporal variations of the surface temperature during the 3-day episode, but in general the model slightly underestimates the observations, particularly in the morning (Fig. 5a).
The MB and RMSE are -0.76 and $1.1{ }^{\circ} \mathrm{C}$, respectively, and the IOA reaches 0.97 , indicating good agreement of the surface temperature simulations with measurements (Table 3 ). The WRF-Chem model generally tracks the temporal variations of the surface relative humidity well, with an IOA of 0.92 (Fig. 5b). However, model underestimation of the observed surface relative humidity is obvious at midnight and during morning. The MB and RMSE are -4.5 and $5.5 \%$ for the surface relative humidity simulations, respectively.

Figures 6 and 7 present the comparisons of simulated and observed wind speeds and directions at six meteorological observation sites from 22 to 24 August 2013, respectively. The model fails to yield the observed temporal variation of the wind speed at the Xi' an site with the IOA of 0.26 and 

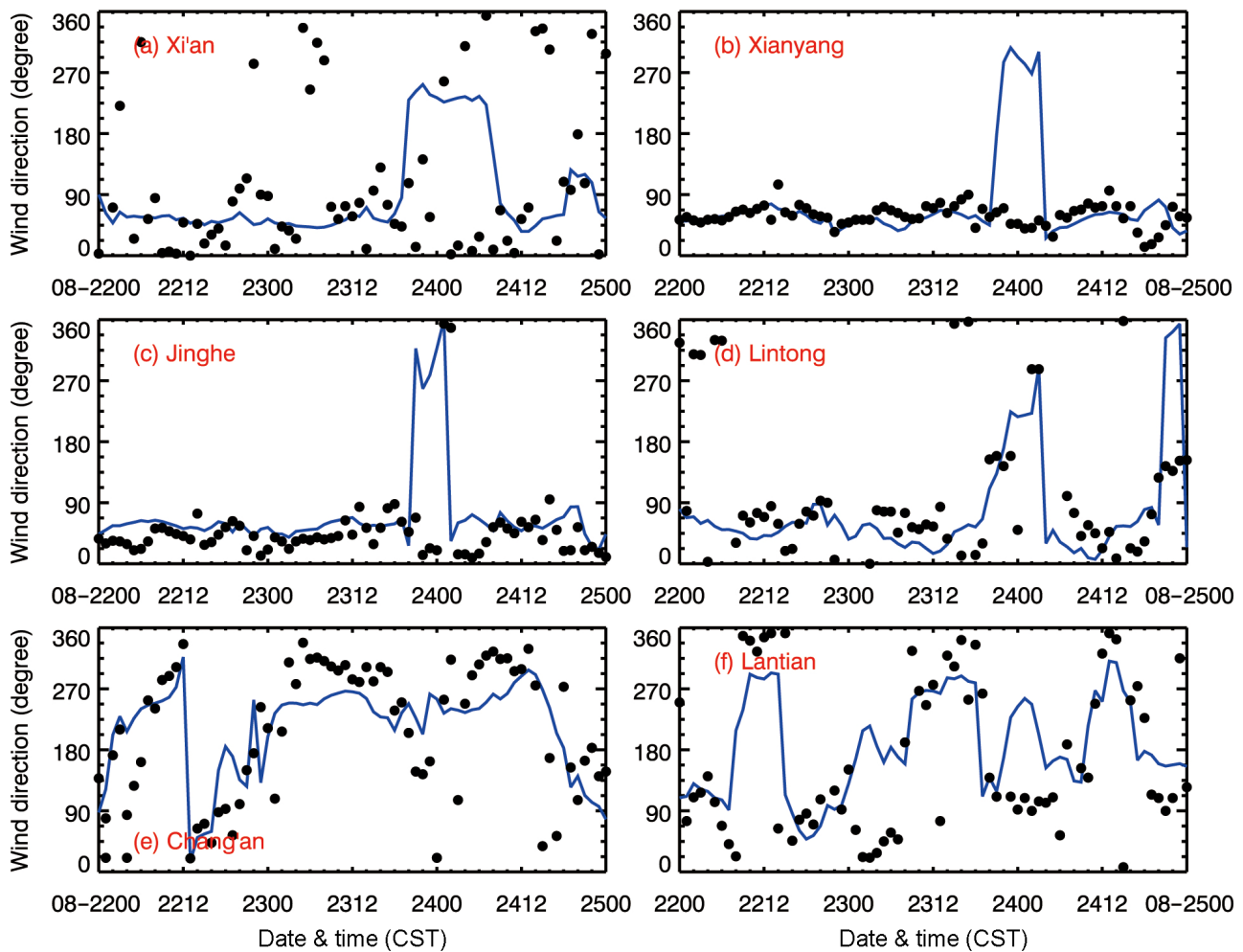

Figure 7. Same as Fig. 6 but for surface wind directions.

Table 2. Summertime $\mathrm{O}_{3}$ and $\mathrm{PM}_{2.5}$ concentrations (averaged in the afternoon) in the main cities of Guanzhong basin, BTH, YRD, and PRD in China during 2013.

\begin{tabular}{llrr}
\hline Region & City & $\mathrm{O}_{3}\left(\mu \mathrm{g} \mathrm{m}^{-3}\right)$ & $\mathrm{PM}_{2.5}\left(\mu \mathrm{g} \mathrm{m}^{-3}\right)$ \\
\hline Guanzhong & Xi'an & 104.6 & 48.5 \\
BTH & Beijing & 133.9 & 74.7 \\
& Tianjin & 116.9 & 78.1 \\
& Shijiazhuang & 140.4 & 86.6 \\
YRD & Shanghai & 122.9 & 47.1 \\
& Hangzhou & 110.5 & 35.0 \\
\multirow{2}{*}{ PRD } & Nanjing & 96.6 & 41.2 \\
& Guangzhou & 94.9 & 29.4 \\
\hline
\end{tabular}

also significantly overestimates the observation with a $\mathrm{MB}$ of $1.7 \mathrm{~m} \mathrm{~s}^{-1}$ and RMSE of $2.1 \mathrm{~m} \mathrm{~s}^{-1}$. In addition, fluctuating wind direction was observed at the Xi' an site; in contrast, the simulated winds remained fixed in a northeasterly direction until the evening of 23 August and then changed to the southwest before noontime of 24 August. As the Xi'an site is located in the urban center of Xi'an, it is surrounded by high buildings which significantly alter the airflow on the ground surface, causing light and disordered surface winds. Although the urban canopy model is utilized in the WRFChem model simulations, the simulated surface winds are still biased considerably in the urban region due to the simpli-
Table 3. Statistical comparison of simulated and measured $\mathrm{O}_{3}$, $\mathrm{NO}_{2}, \mathrm{PM}_{2.5}$, temperature, relative humidity, and wind speed at monitoring sites from 22 to 24 August 2013.

\begin{tabular}{llrrl}
\hline Predictands & Classification & MB & RMSE & IOA \\
\hline $\mathrm{O}_{3}\left(\mu \mathrm{g} \mathrm{m}^{-3}\right)$ & Averaged & -9.0 & 29.0 & 0.91 \\
$\mathrm{NO}_{2}\left(\mu \mathrm{g} \mathrm{m}^{-3}\right)$ & Averaged & -5.2 & 11.0 & 0.73 \\
$\mathrm{PM}_{2.5}\left(\mu \mathrm{g} \mathrm{m}^{-3}\right)$ & Averaged & -1.4 & 21.0 & 0.92 \\
Temperature $\left({ }^{\circ} \mathrm{C}\right)$ & Averaged & -0.76 & 1.1 & 0.97 \\
Relative humidity (\%) & Averaged & -4.5 & 5.5 & 0.92 \\
Wind speed (m s$\left.{ }^{-1}\right)$ & Xi' an & 1.7 & 2.1 & 0.26 \\
& Xianyang & 1.3 & 1.5 & 0.61 \\
& Jinghe & 0.14 & 1.1 & 0.74 \\
& Lintong & 1.2 & 1.5 & 0.63 \\
& Chang'an & 0.69 & 1.2 & 0.47 \\
& Lantian & 0.43 & 1.1 & 0.61 \\
\hline
\end{tabular}

fication of building distributions and heights and the inability of the model for microscale simulations (Chen et al., 2011; Lee et al., 2011). The simulated winds at the Xi' an site are similar to those at the Lintong, Xianyang, and Jinghe sites in the north of Xi'an, but in general, the wind simulations at these three sites are in good agreement with the observations, with an IOA of at least 0.61 for the wind speed, further suggesting the impacts of buildings in the urban region on the wind simulations. The model performs well in predicting the wind speed and direction at the Chang'an and Lantian 

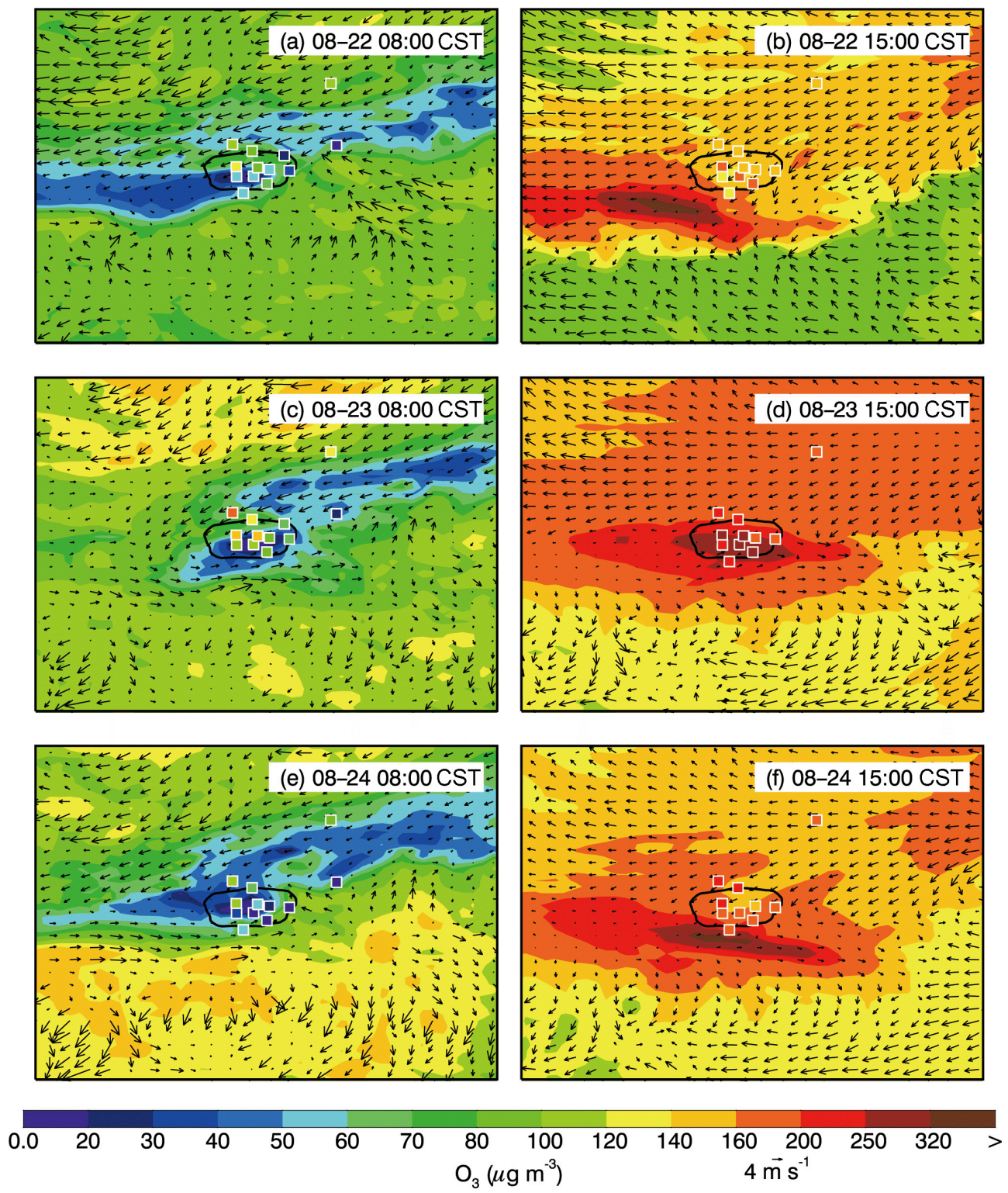

Figure 8. Pattern comparison of simulated vs. observed near-surface $\mathrm{O}_{3}$ concentrations at 08:00 and 15:00 CST from 22 to 24 August 2013. Colored squares: $\mathrm{O}_{3}$ observations; color contour: $\mathrm{O}_{3}$ simulations; black arrows: simulated surface winds.

sites in the south of Xi'an. It should be noted that the model considerably overestimates the observed wind speeds at all observations sites in the early morning of 23 August and also fails to track the variation of wind directions over the sites in the southern part of Xi' an, which causes the biased dispersion of the plume formed during daytime. In addition, the overestimation of the wind speed is also remarkable in the afternoon and evening of 24 August, and this evacuates the plume formed in the urban region more efficiently.

\subsubsection{Gas-phase species simulations}

The modeled $\mathrm{O}_{3}$ and $\mathrm{NO}_{2}$ mass concentrations are compared to the measurements at the ambient monitoring stations re- leased by China MEP. Figure 8 shows the spatial distributions of calculated and observed near-surface $\mathrm{O}_{3}$ concentrations at 08:00 and 15:00 China Standard Time (CST) from 22 to 24 August 2013, along with the simulated wind fields. When the northeast wind is prevalent in the Guanzhong basin, due to the impact of the topography (Fig. 1), stagnant conditions are frequently formed in Xi' an and surrounding areas. At 08:00 CST, the model underestimates the observed near-surface $\mathrm{O}_{3}$ concentrations in the urban area of Xi'an, which is perhaps caused by the titration of $\mathrm{NO}$ emitted from traffic during rush hours. At 15:00 CST, the calculated nearsurface $\mathrm{O}_{3}$ distributions are generally consistent with the observations at the ambient monitoring sites. On 22 August the 

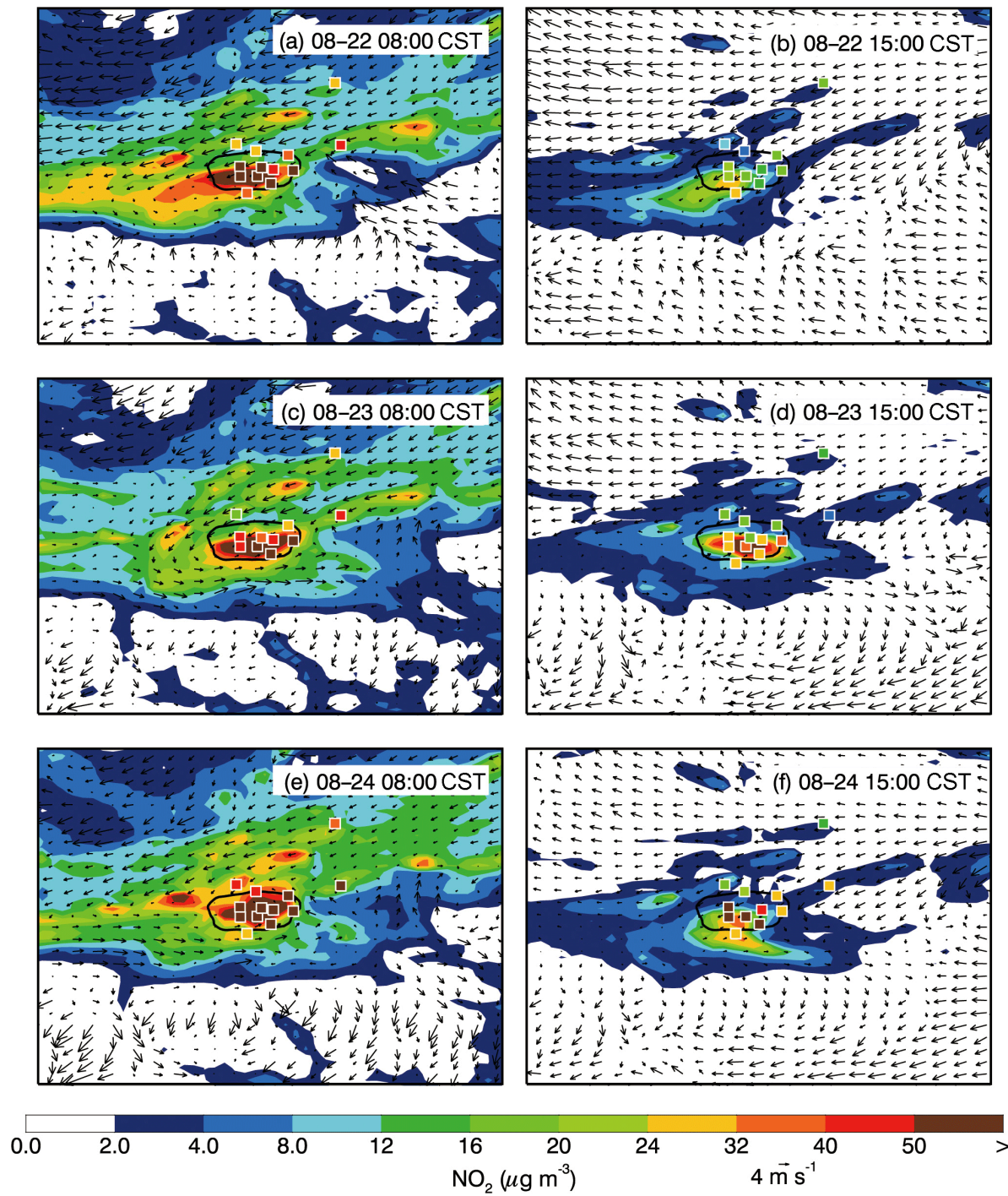

Figure 9. Pattern comparison of simulated vs. observed near-surface $\mathrm{NO}_{2}$ concentrations at 08:00 and 15:00 CST from 22 to 24 August 2013 . Colored squares: $\mathrm{NO}_{2}$ observations; color contour: $\mathrm{NO}_{2}$ simulations; black arrows: simulated surface winds.
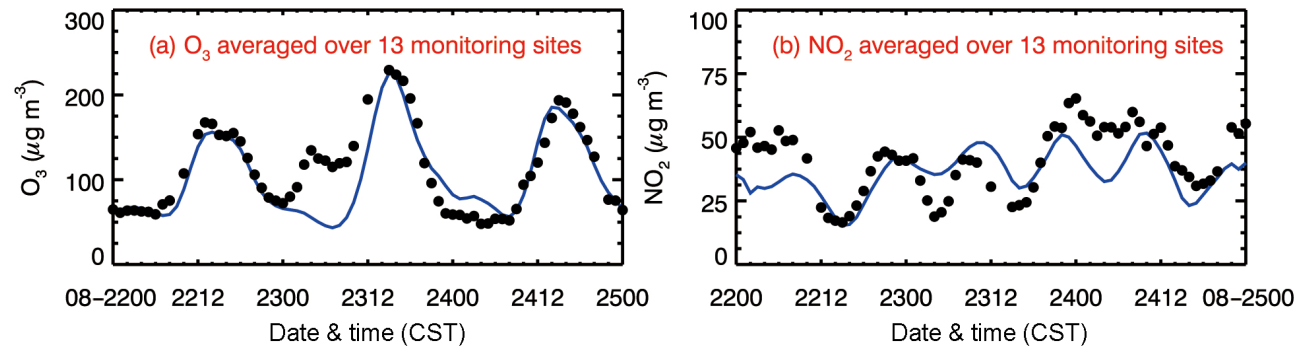

Figure 10. Comparison of measured (black dots) and simulated (blue line) diurnal profiles of near-surface hourly (a) $\mathrm{O}_{3}$ and (b) $\mathrm{NO}_{2}$ averaged over all ambient monitoring stations from 22 to 24 August 2013.

northeast winds were strong and the stagnant region with high $\mathrm{O}_{3}$ plume was located in the southwest of Xi' an and surrounding areas; the predicted $\mathrm{O}_{3}$ concentrations are less than $160 \mu \mathrm{g} \mathrm{m}^{-3}$ in the urban area of Xi' an, in good agree- ment with the measurements. On 23 August the convergence in the urban area of $\mathrm{Xi}$ ' an was favorable for the accumulation of $\mathrm{O}_{3}$ precursors and a high $\mathrm{O}_{3}$ plume was formed in the afternoon, with the $\mathrm{O}_{3}$ concentration exceeding $200 \mu \mathrm{g} \mathrm{m}^{-3}$. 


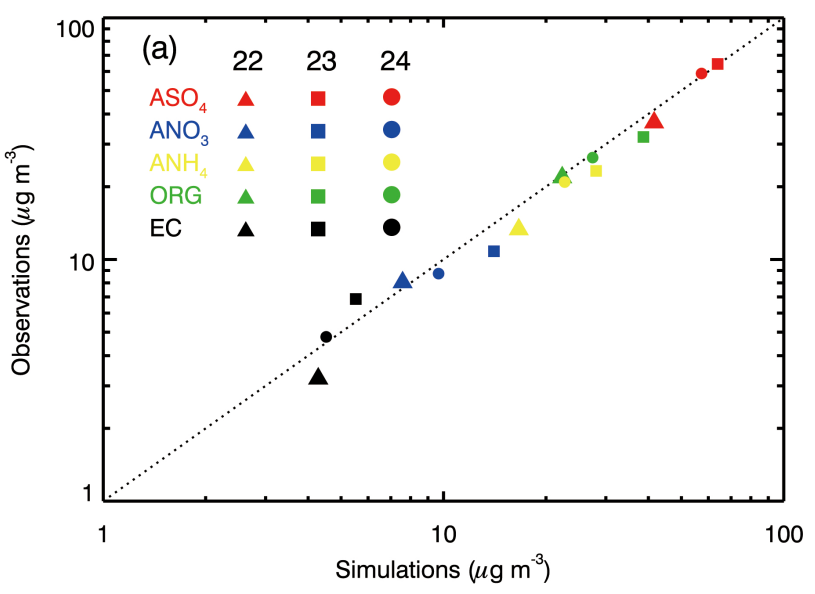

Observed $\mathrm{PM}_{2.5}\left(148 \mu \mathrm{g} \mathrm{m}^{-3}\right) \quad$ Modeled $\mathrm{PM}_{2.5}\left(134 \mu \mathrm{g} \mathrm{m}^{-3}\right)$

\section{(b)}

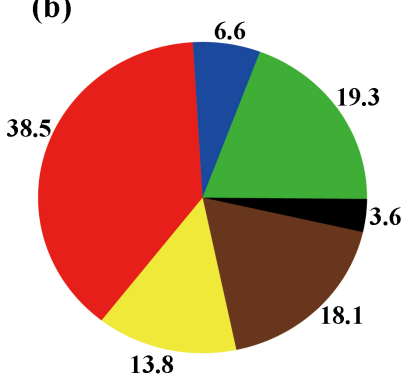

(c)

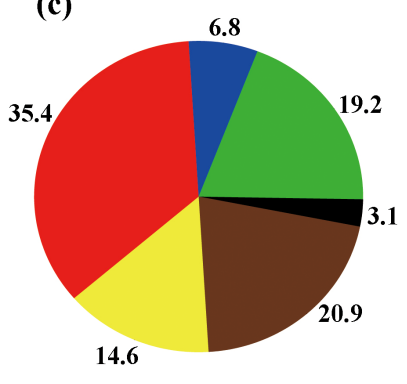

EC

Unspecified

ASO4

Figure 11. Panel (a): scatterplot of measured daily aerosol constituents with simulations and comparison of (b) measured and (c) modeled $\mathrm{PM}_{2.5}$ chemical composition (\%).

On 24 August the plume formed in the urban region of Xi' an was pushed to the south of $\mathrm{Xi}$ 'an and surrounding areas in the afternoon and the simulated $\mathrm{O}_{3}$ concentrations were less than $200 \mu \mathrm{g} \mathrm{m}^{-3}$ in the urban area of Xi' an, generally consistent with the observations. In addition, the $\mathrm{O}_{3}$ level in Xi' an and surrounding areas was also affected by the $\mathrm{O}_{3}$ transport from its upwind region. It is worth noting that the model cannot replicate reasonably the spatial variation of the observed $\mathrm{O}_{3}$ concentration at monitoring sites in the urban area of Xi' an. Although $3 \mathrm{~km}$ horizontal resolution is used in the study, it still cannot resolve adequately the spatial variation of $\mathrm{O}_{3}$ concentrations over monitoring sites with a distance of less than $21 \mathrm{~km}$ (Skamarock, 2004). Unfortunately, the ambient monitoring sites in Xi'an are mainly concentrated in the urban area (around $20 \mathrm{~km} \times 30 \mathrm{~km}$ ); thus, future model studies with higher horizontal resolution will be needed to improve the near-surface $\mathrm{O}_{3}$ simulations under the present monitoring site distribution.

The simulated near-surface $\mathrm{NO}_{2}$ distributions agree well with the observations at the ambient monitoring sites in the morning (Fig. 9a, c, and e), with the highest $\mathrm{NO}_{2}$ concentration in the urban center of Xi' an. In the afternoon, the model

overestimates the observation in the urban center on $23 \mathrm{Au}$ gust, while it underestimates the observation on 24 August.

Figure 10 displays the diurnal profiles of predicted and observed near-surface $\mathrm{O}_{3}$ and $\mathrm{NO}_{2}$ concentrations averaged over the ambient monitoring sites during the episode. The model tracks the temporal variations of surface $\mathrm{O}_{3}$ concentrations well during daytime (Fig. 10a), but the simulated $\mathrm{O}_{3}$ concentrations deviate markedly from the observations in the early morning hours on 23 August. Apparently, the plume with high $\mathrm{O}_{3}$ concentrations formed in the southwest of Xi' an during daytime (Fig. 8b) on 22 August was transported back to the urban area of Xi' an in the early morning on 23 August causing the observed high $\mathrm{O}_{3}$ level. However, due to biases of the wind simulations in the early morning on 23 August (Figs. 6 and 7), the plume formed from the previous day was not transported back to the urban area of Xi' an, leading to the remarkable underestimation of the observed $\mathrm{O}_{3}$ concentrations. The MB, RMSE, and IOA of the simulated $\mathrm{O}_{3}$ concentration averaged over monitoring stations are -9.0 and $29 \mu \mathrm{g} \mathrm{m}^{-3}$ and 0.91 , respectively. Although the model reasonably well reproduces the variation of the observed $\mathrm{NO}_{2}$ concentrations (Fig. 10b), with an IOA of 0.73 , it often overestimates or underestimates the observation. Uncertainties in the simulated meteorological fields or the emission inventory might be responsible for the model biases in simulating $\mathrm{NO}_{2}$ distributions and variations.

In summary, the calculated distribution and variation of near-surface $\mathrm{O}_{3}$ and $\mathrm{NO}_{2}$ concentrations are in good agreement with the corresponding observations, suggesting that the model simulates well the meteorological fields and that the emission inventory used in the study is also reasonable.

\subsubsection{Aerosol simulations}

Atmospheric particulate matter or aerosols scatter or absorb a fraction of solar radiation and increase or decrease the photolysis rates in the atmosphere, influencing the $\mathrm{O}_{3}$ formation. Therefore, in order to reasonably verify the aerosol impact on the photolysis and $\mathrm{O}_{3}$ level, it is important to evaluate the simulated aerosol composition, variation, and distribution using available measurements. Daily measurement of aerosol constituents is performed using the filter sample at the IEECAS site, including sulfate, nitrate, ammonium, organic, and elemental carbon. Figure 11a presents a scatterplot of the measured versus calculated daily mean concentration of aerosol constituents at the IEECAS site from 22 to 24 August 2013. It should be noted that the simulated organic aerosol is compared with the filter-measured organic carbon scaled by a factor of 2 (Carlton et al., 2010). The model performs well in simulating daily mean sulfate and organic aerosol concentrations. The model tends to overestimate the observed nitrate and ammonium concentration; this might be caused by the nitrate loss due to the evaporation from filters in the summer (Ianniello et al., 2011). The simulated daily mean elemental carbon concentrations deviate 

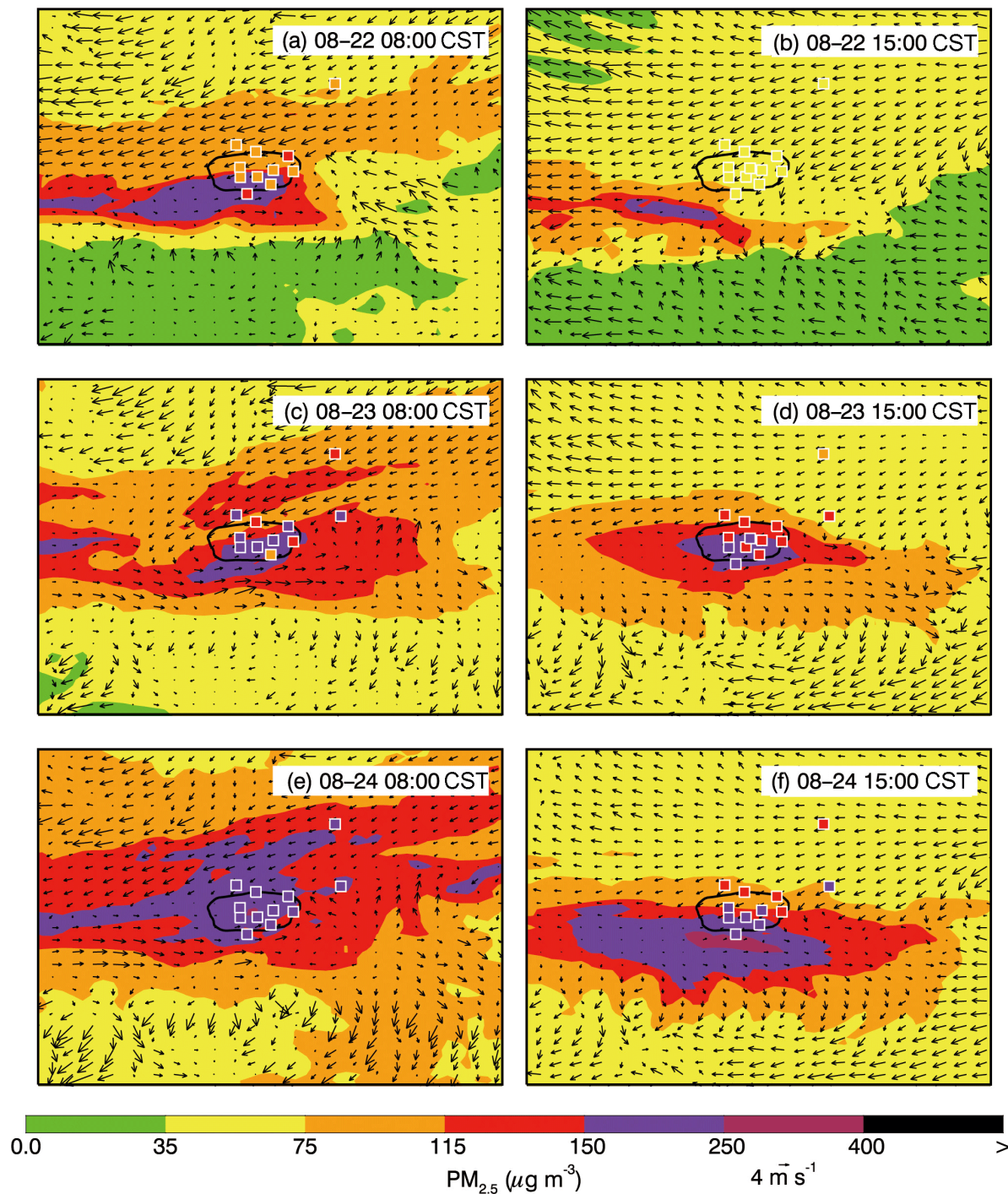

Figure 12. Pattern comparison of simulated vs. observed near-surface $\mathrm{PM}_{2.5}$ concentrations at 08:00 and 15:00 CST from 22 to 24 August 2013. Colored squares: $\mathrm{PM}_{2.5}$ observations; color contour: $\mathrm{PM}_{2.5}$ simulations; black arrows: simulated surface winds.

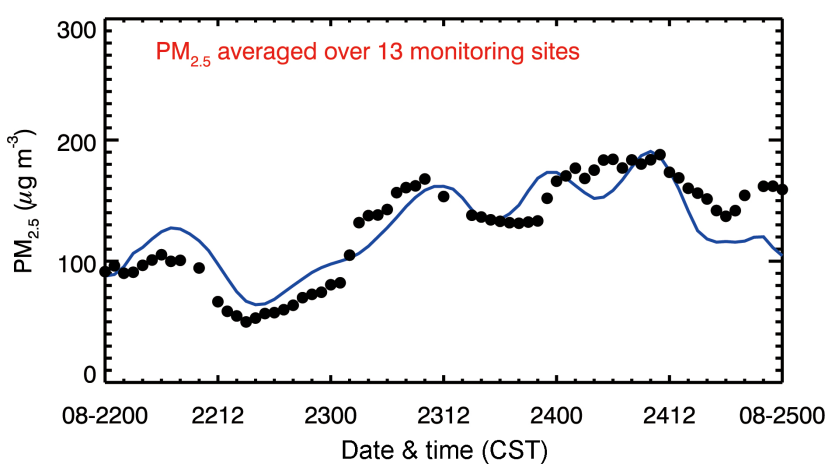

Figure 13. Comparison of measured (black dots) and simulated (blue line) diurnal profiles of near-surface hourly $\mathrm{PM}_{2.5}$ averaged over all ambient monitoring stations from 22 to 24 August 2013. from the measurements considerably on 22 and 23 August, which is perhaps caused by the daily variations of elemental carbon emissions. Comparison of the observed and modeled $\mathrm{PM}_{2.5}$ mass composition averaged during the 3-day episode is displayed in Fig. $11 \mathrm{~b}$ and c. Sulfate is the dominant constituent of the observed $\mathrm{PM}_{2.5}$ at the IEECAS site, consisting of around $39 \%$ of the $\mathrm{PM}_{2.5}$ mass, and the simulated sulfate contribution to the $\mathrm{PM}_{2.5}$ mass is about $35 \%$ on average, close to the observation. The high sulfate concentrations come mainly from the $\mathrm{SO}_{2}$ heterogeneous reaction on aerosol surfaces under humid conditions (Wang et al., 2014). The measured and modeled organic aerosols make up about $19 \%$ of the $\mathrm{PM}_{2.5}$ mass at the IEECAS site, and secondary organic aerosol contributes more than $50 \%$ of the modeled organic aerosol due to the high atmospheric oxidation capacity in the summer. The modeled ammonium, nitrate, and el- 

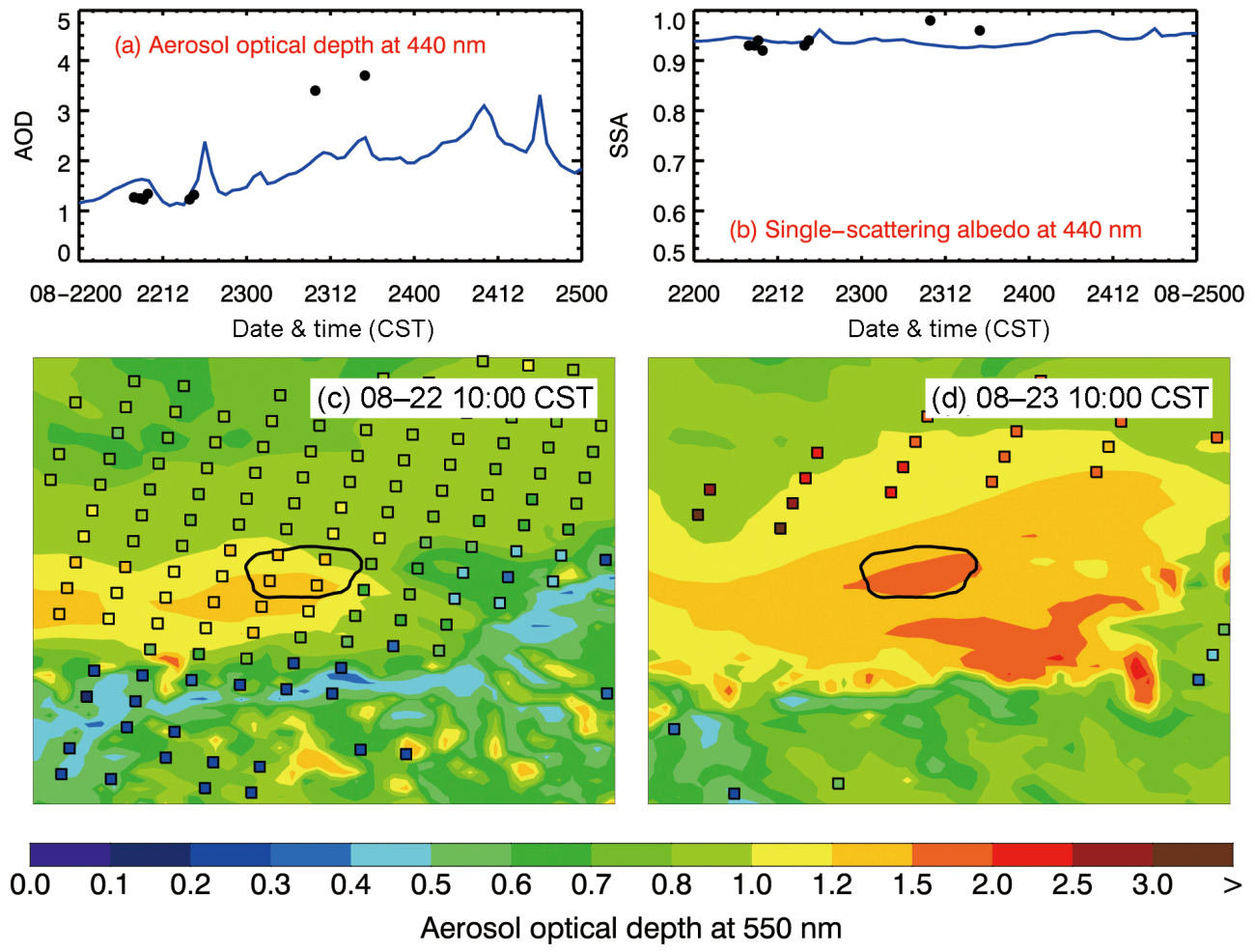

Figure 14. Retrieved (black dots) and calculated (blue lines) diurnal profiles of (a) AOD and (b) aerosol SSA at $440 \mathrm{~nm}$ at the IEECAS site from 22 to 24 August 2013 and pattern comparison of calculated vs. retrieved AOD at 550 nm at 10:00 CST on (c) 22 August and (d) 23 August 2013. Colored squares: retrieved AOD; color contour: calculated AOD.
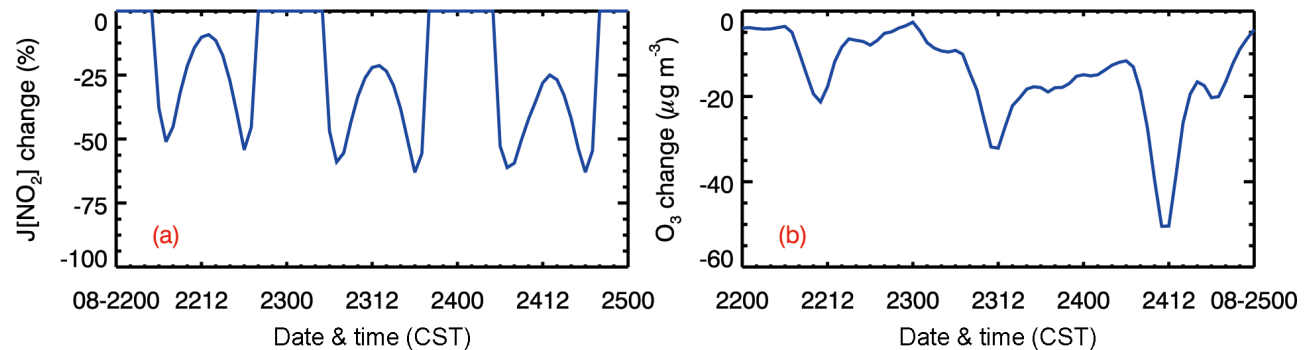

Figure 15. Diurnal variations of the change in (a) $J\left[\mathrm{NO}_{2}\right]$ and (b) $\mathrm{O}_{3}$ concentrations averaged in Xi' an and surrounding areas due to aerosol effects from 22 to 24 August 2013.

emental carbon account for about $15,6.8$, and $3.1 \%$ of the $\mathrm{PM}_{2.5}$ mass, respectively, comparable to the observed 14 , 6.6 , and $3.6 \%$ at the IEECAS site.

Figure 12 shows the simulated geographic distributions of near-surface $\mathrm{PM}_{2.5}$ mass concentrations and the observations over the monitoring stations at 08:00 and 15:00 CST from 22 to 24 August. On 22 August the convergence is formed in the north of Xi' an and surrounding areas at 08:00 CST, leading to the buildup of pollutants and high $\mathrm{PM}_{2.5}$ concentrations. The simulated $\mathrm{PM}_{2.5}$ concentrations are more than $75 \mu \mathrm{g} \mathrm{m}^{-3}$ in the north of Xi'an and surrounding areas, consistent with the measurements, but exceed $150 \mu \mathrm{g} \mathrm{m}^{-3}$ in the south, where stagnant conditions are formed, and are much higher than the observation. At 15:00 CST, well organized northeast winds push the convergence zone to the southeast of Xi' an and surrounding areas and the simulated $\mathrm{PM}_{2.5}$ concentrations are less than $75 \mu \mathrm{g} \mathrm{m}^{-3}$, in good agreement with the measurements. On 23 August the convergence is held within in the urban area of Xi' an, causing heavy $\mathrm{PM}_{2.5}$ pollution. The calculated $\mathrm{PM}_{2.5}$ concentration is more than $115 \mu \mathrm{g} \mathrm{m}^{-3}$ at $08: 00$ and 15:00 CST, comparable to the measurements. The observed and simulated $\mathrm{PM}_{2.5}$ patterns on 23 August are similar to those on 23 August but the $\mathrm{PM}_{2.5}$ concentrations on 24 August are enhanced. For example, the observed and simulated $\mathrm{PM}_{2.5}$ concentrations over all monitoring stations exceed $150 \mu \mathrm{g} \mathrm{m}^{-3}$ at 08:00 CST. In addition, at 15:00 CST, 

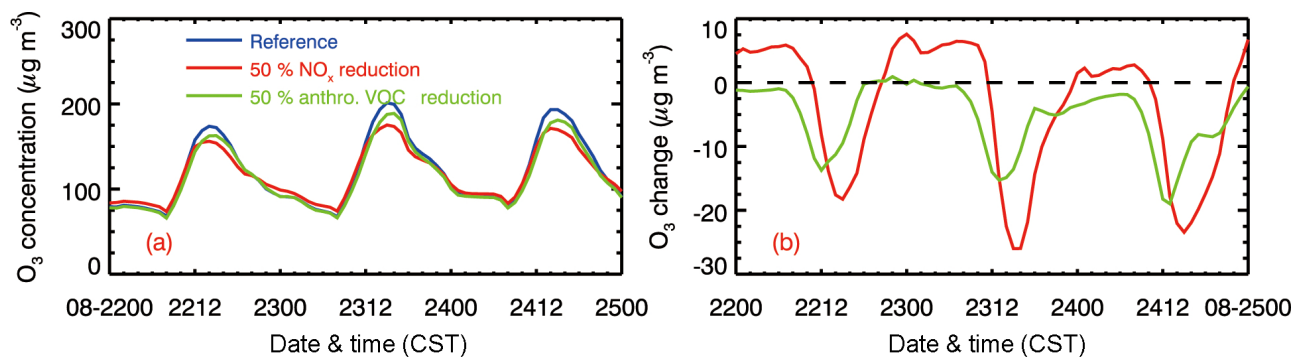

Figure 16. Diurnal profiles of (a) $\mathrm{O}_{3}$ concentrations and (b) $\mathrm{O}_{3}$ changes averaged in Xi' an and surrounding areas caused by a $50 \%$ reduction in anthropogenic $\mathrm{NO}_{x}$ and VOC emissions, respectively, from 22 to 24 August 2013. Blue line: the reference simulation; red line: the simulation with a $50 \%$ reduction in anthropogenic $\mathrm{NO}_{x}$ emissions; green line: the simulation with a $50 \%$ reduction in anthropogenic VOC emissions.

due to the overestimation of the wind speed (Fig. 6), the convergence zone is pushed to the south of Xi' an and surrounding areas, causing the underestimation of $\mathrm{PM}_{2.5}$ concentration in the north. The model reproduces the observed diurnal profile of the $\mathrm{PM}_{2.5}$ concentration averaged over the monitoring stations during the episode (Fig. 13), with a MB of $-1.4 \mu \mathrm{g} \mathrm{m}^{-3}$, an RMSE of $21 \mu \mathrm{g} \mathrm{m}^{-3}$, and an IOA of 0.92. Apparently, the convergence zone location, which is determined by the meteorological fields, significantly influences the $\mathrm{PM}_{2.5}$ simulations. When the simulated convergence zone is formed in the south of Xi' an and surrounding areas on the morning of 22 August, the model considerably overestimates the observed $\mathrm{PM}_{2.5}$ concentration. However, when the simulated winds are too strong and the convergence zone is pushed to the south of $\mathrm{Xi}$ 'an and surrounding areas on 23 August, the model notably underestimates the observations.

The simulated column-integrated aerosol optical depth (AOD) and single-scattering albedo (SSA) are verified using the available measurements from the surface site and satellite. The simulated aerosol optical properties are calculated using the method developed by Li et al. (2011b). Figure 14a and $b$ show the comparison of simulated column-integrated AOD and aerosol SSA, respectively, at $440 \mathrm{~nm}$ with measurements at the IEECAS site, which are retrieved from the observations of a sun-sky radiometer (Su et al., 2014). The simulated AOD on 22 August is comparable to the measurements at the IEECAS site, but the WRF-Chem model overestimates the observation in the morning due to the overestimation of $\mathrm{PM}_{2.5}$ concentrations. The simulated SSA on $22 \mathrm{Au}-$ gust ranges from 0.92 to 0.95 , close to the measurement. However, on 23 August, the retrieved AOD and SSA exceed 3.0 and 0.95 , respectively, higher than the corresponding simulations. The underestimation of the simulated AOD and aerosol SSA could be attributed to the underestimation of the relative humidity, not limited to the ground surface as shown in Fig. 5. The distribution of the calculated AOD at $550 \mathrm{~nm}$ from the MODIS (Moderate Resolution Imaging Spectroradiometer) aerosol level-2 product at $5 \times 51 \mathrm{~km}$ pixel resolution is also compared with the model results (Fig. 14c and d). The simulated AOD pattern on 22 August agrees well with the measurements, except over the Qin Ling where the convection is active. The model underestimates the observed AOD in the north of Xi' an on 23 August, which is likely caused by the bias of the simulated relative humidity. Apparently, the AOD at $550 \mathrm{~nm}$ in $\mathrm{Xi}^{\prime}$ an and surrounding areas is high, exceeding 0.8 on 22 August and 1.0 on 23 August.

\subsection{Sensitivity studies}

\subsubsection{Effects of aerosol on the $\mathrm{O}_{3}$ formation}

$\mathrm{O}_{3}$ formation in the atmosphere is a complicated photochemical process, which is determined by its precursors from various sources and transformation in the presence of sunlight. High AOD in Xi' an and the surrounding areas efficiently scatter or absorbs sunlight to decrease the photolysis frequencies in the planetary boundary layer (PBL) and further the $\mathrm{O}_{3}$ formation. High $\mathrm{O}_{3}$ levels enhance atmospheric oxidation capability and the secondary aerosol formation, increasing the aerosol concentration in the atmosphere, but conversely, high aerosol levels decrease the photolysis frequencies and suppress the $\mathrm{O}_{3}$ formation in the PBL. The interactions of $\mathrm{O}_{3}$ with aerosols complicate the design of $\mathrm{O}_{3}$ control strategies.

The aerosol effect on $\mathrm{O}_{3}$ formation in Xi' an and surrounding areas is examined by the sensitivity study without aerosol effects on the photolysis compared to the reference simulation (hereafter, we define the sensitivity simulation as SEN). Figure $15 \mathrm{a}$ and $\mathrm{b}$ present the diurnal profiles of the change in the $\mathrm{NO}_{2}$ photolysis frequency $\left(J\left[\mathrm{NO}_{2}\right]\right)$ and $\mathrm{O}_{3}$ concentration, respectively, averaged in Xi' an and surrounding areas due to aerosol effects from 22 to 24 August. Aerosols significantly decrease $J\left[\mathrm{NO}_{2}\right]$ by $30-70 \%$ (defined as (REFSEN)/SEN) in the early morning and late afternoon hours when the solar zenith angle is large, showing the impact of a long aerosol optical path for incoming radiation. Due to the high aerosol level, the aerosol effect on $J\left[\mathrm{NO}_{2}\right]$ is still substantial during noontime, decreasing $J\left[\mathrm{NO}_{2}\right]$ by over $20 \%$ on 23 and 24 August when the plume is stagnant in the urban region of Xi'an. The aerosol effect on the photoly- 

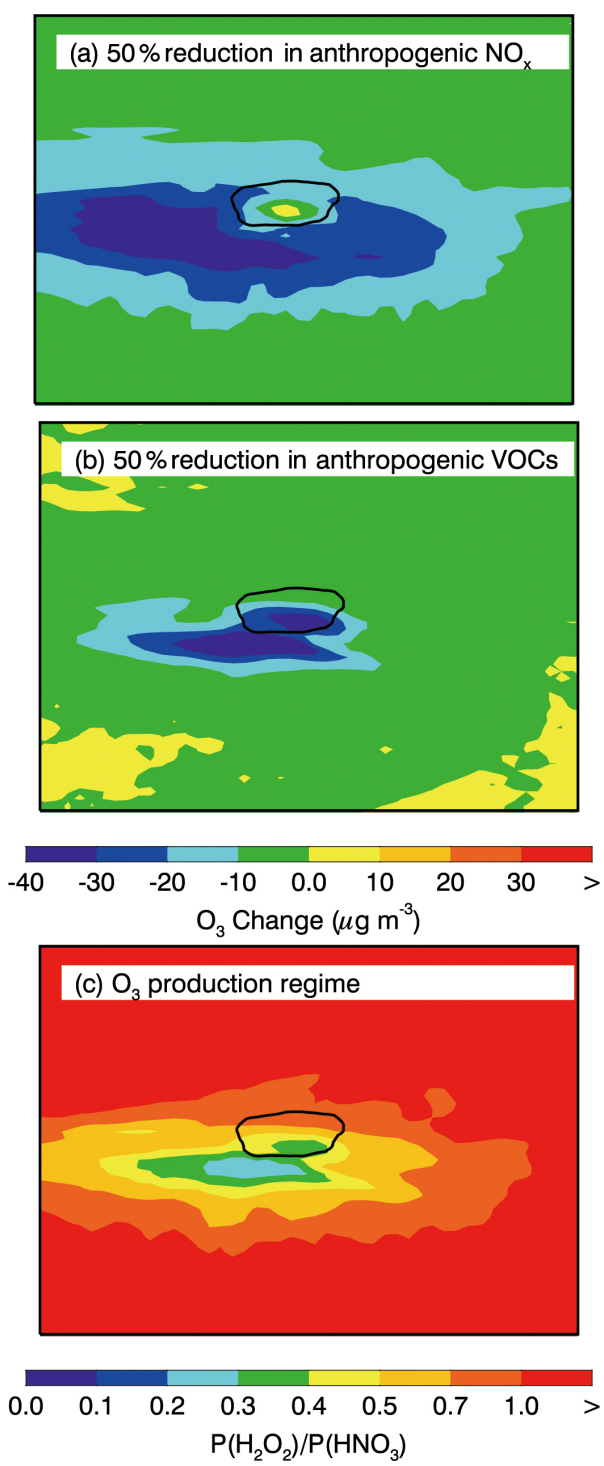

Figure 17. Change in $\mathrm{O}_{3}$ concentrations in the bottom model layer, averaged during $\mathrm{O}_{3}$ peak time from 22 to 24 August 2013 due to a $50 \%$ reduction in anthropogenic (a) $\mathrm{NO}_{x}$ and (b) VOC emissions and the 3-day average ratio of $P\left(\mathrm{H}_{2} \mathrm{O}_{2}\right) / P\left(\mathrm{HNO}_{3}\right)$ during $\mathrm{O}_{3}$ peak time.

sis frequency in this study is larger than those reported in other studies (e.g., Jacobson, 1998; Li et al., 2005, 2011b). The aerosol impact on $\mathrm{O}_{3}$ formation is most significant during the late morning and early afternoon (Fig. 15b). On average, in Xi' an and surrounding areas, the reduction in $\mathrm{O}_{3}$ concentration (defined as (REF-SEN)) due to the aerosol effect on photolysis is less than $20 \mu \mathrm{g} \mathrm{m}^{-3}$ on 22 August but more than $30 \mathrm{\mu g} \mathrm{m}^{-3}$ during noontime on 23 August and over $50 \mu \mathrm{g} \mathrm{m}^{-3}$ in the late morning on 24 August. The aerosol effect on $\mathrm{O}_{3}$ formation in this study is comparable to those reported by Castro et al. (2001) in Mexico City. It should be noted that the impact of photolysis on $\mathrm{O}_{3}$ level varies de- pending on the ratio of VOCs to $\mathrm{NO}_{x}$ (Stockwell and Goliff, 2004). The important aerosol effects on $\mathrm{O}_{3}$ formation may pose a dilemma for $\mathrm{O}_{3}$ control strategies. If $\mathrm{O}_{3}$ concentrations are decreased by reducing its precursor's emissions, the aerosol level will also decrease due to direct and indirect contributions from the emission control, which compensates for the $\mathrm{O}_{3}$ reduction by enhancing the photolysis frequency.

\subsection{2 $\mathrm{O}_{3}$ response to emission changes}

In the urban area, when the meteorological conditions are favorable for the accumulation of pollutants in the PBL, the $\mathrm{O}_{3}$ precursors of anthropogenically or naturally emitted VOCs and $\mathrm{NO}_{x}$, react chemically in the presence of sunlight, leading to high $\mathrm{O}_{3}$ level. In order to devise an effective $\mathrm{O}_{3}$ control strategy, it is important to investigate the regime of $\mathrm{O}_{3}$ production. The regime of $\mathrm{O}_{3}$ production in $\mathrm{Xi}$ ' an and surrounding areas is examined using sensitivity studies by reducing anthropogenic VOC (AVOC) or $\mathrm{NO}_{x}$ emissions by $50 \%$ in the WRF-Chem simulations. Figure 16 compares the near-surface $\mathrm{O}_{3}$ concentrations averaged in the urban area of $\mathrm{Xi}$ 'an in the reference simulation to the two sensitivity studies in which AVOCs and $\mathrm{NO}_{x}$ are decreased by $50 \%$. A $50 \%$ reduction in AVOCs decreases the $\mathrm{O}_{3}$ concentration averaged in the areas around $\mathrm{Xi}$ ' an consistently during the episode, particularly during peak time (defined as 14:00-16:00 CST hereafter). A $50 \%$ reduction in $\mathrm{NO}_{x}$ enhances the $\mathrm{O}_{3}$ level in the morning due to the decrease in $\mathrm{NO}$ emission; but in the afternoon, it decreases the $\mathrm{O}_{3}$ level, similar to the effect from a $50 \%$ reduction in AVOCs, leading to a complicated $\mathrm{O}_{3}$ production regime.

Figure 17a shows the 3-day average near-surface $\mathrm{O}_{3}$ change during peak time with a $50 \%$ reduction in $\mathrm{NO}_{x}$ emissions (defined as $\mathrm{O}_{3}(\mathrm{SEN})-\mathrm{O}_{3}(\mathrm{REF})$ ). In $\mathrm{Xi}$ ' an and surrounding areas, except the urban center, the simulated average $\mathrm{O}_{3}$ concentrations are decreased by about $10-40 \mu \mathrm{g} \mathrm{m}^{-3}$ due to a $50 \%$ reduction in $\mathrm{NO}_{x}$. In the urban center, the $\mathrm{O}_{3}$ concentrations are slightly enhanced (less than $10 \mu \mathrm{g} \mathrm{m}^{-3}$ ) with the high decrease in $\mathrm{NO}_{x}$ emissions. A $50 \%$ reduction in AVOC emissions consistently reduces the $\mathrm{O}_{3}$ concentration in Xi' an and surrounding areas by up to $40 \mu \mathrm{g} \mathrm{m}^{-3}$ (Fig. 17b). The response of $\mathrm{O}_{3}$ change to a $50 \%$ reduction in $\mathrm{NO}_{x}$ or AVOC emissions cannot clearly indicate the $\mathrm{O}_{3}$ production regime in $\mathrm{Xi}$ ' an and surrounding areas.

Sillman (1995) proposed that the ratio of the production rates of hydrogen peroxide and nitric acid $\left(P\left(\mathrm{H}_{2} \mathrm{O}_{2}\right) / P\left(\mathrm{HNO}_{3}\right)\right)$ can be used to investigate the sensitivity of ozone formation to the precursors. If the ratio of $P\left(\mathrm{H}_{2} \mathrm{O}_{2}\right) / P\left(\mathrm{HNO}_{3}\right)$ is less than 0.3 , the $\mathrm{O}_{3}$ production regime is VOC-sensitive. If the ratio exceeds 0.5 , the regime is $\mathrm{NO}_{x}$-sensitive. The ratio ranging from 0.3 to 0.5 indicates the transition from $\mathrm{NO}_{x}$ - to VOC-sensitive regime. Figure $17 \mathrm{c}$ displays the distribution of the 3-day average $P\left(\mathrm{H}_{2} \mathrm{O}_{2}\right) / P\left(\mathrm{HNO}_{3}\right)$ during the $\mathrm{O}_{3}$ peak time. In Xi'an and surrounding areas, the $P\left(\mathrm{H}_{2} \mathrm{O}_{2}\right) / P\left(\mathrm{HNO}_{3}\right)$ ratio varies 

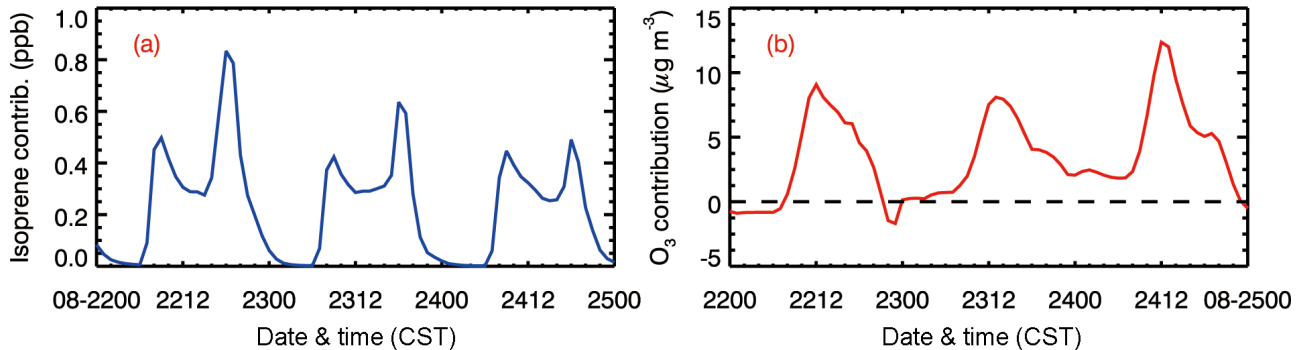

Figure 18. Diurnal variations of contributions of biogenic emissions to near-surface isoprene and $\mathrm{O}_{3}$ concentrations averaged in $\mathrm{Xi}$ ' an and surrounding areas from 22 to 24 August 2013.
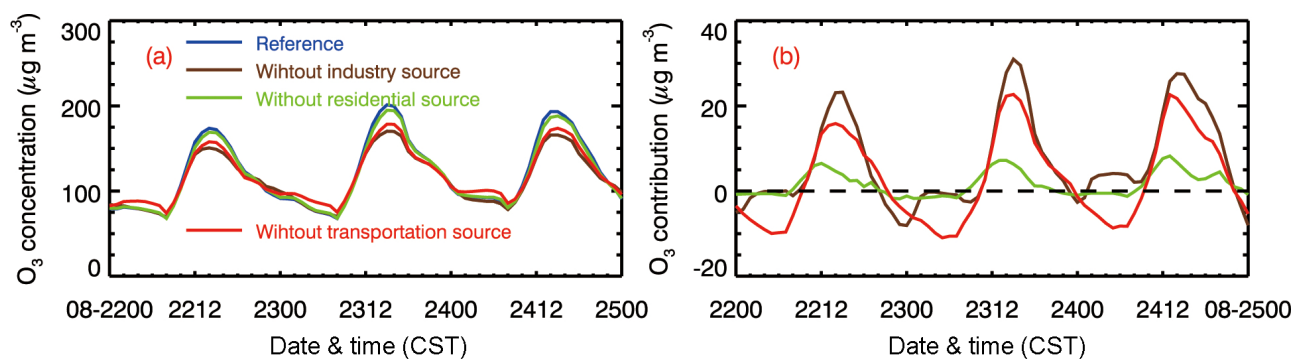

Figure 19. Diurnal profiles of (a) $\mathrm{O}_{3}$ concentrations and (b) $\mathrm{O}_{3}$ contribution from various anthropogenic sources averaged in Xi'an and surrounding areas from 22 to 24 August 2013. Blue line: the reference simulation; brown line: the simulation without industry emissions; green line: the simulation without residential emissions; red line: the simulation without transportation emissions.

from 0.2 to 1.0 , suggesting that the $\mathrm{O}_{3}$ production regime is very complicated. In the south of Xi' an and surrounding areas, the $\mathrm{O}_{3}$ production regime lies in the transition from $\mathrm{NO}_{x}$ to VOC-sensitive chemistry. The analyses using the $P\left(\mathrm{H}_{2} \mathrm{O}_{2}\right) / P\left(\mathrm{HNO}_{3}\right)$ indicator and the results obtained from the two sensitivity studies suggested that it is not straightforward to devise effective $\mathrm{O}_{3}$ control strategies for $\mathrm{Xi}$ ' an and the surrounding areas.

\subsection{3 $\mathrm{O}_{3}$ contribution from natural and anthropogenic sources}

Biogenic emissions provide natural $\mathrm{O}_{3}$ precursors and numerous studies have shown that biogenic VOCs play an important role in ground-level $\mathrm{O}_{3}$ formation in the urban areas (e.g., Solmon et al., 2004; Li et al., 2007), thus complicating $\mathrm{O}_{3}$ control strategy. A sensitivity study without biogenic emissions is conducted and compared with the reference simulation to evaluate the contribution of biogenic emissions to ozone production. During noontime, biogenic emissions contribute about $0.3 \mathrm{ppb}$ isoprene averaged in $\mathrm{Xi}$ ' an and surrounding areas, and the $\mathrm{O}_{3}$ contribution from biogenic emissions is around $10 \mu \mathrm{g} \mathrm{m}^{-3}$ (Fig. 18). Large amounts of biogenic emissions are released over the Qin Ling to the south of Xi' an, and can be transported to the urban area under favorable meteorological conditions, enhancing $\mathrm{O}_{3}$ formation. However, the northeast wind is prevalent in the Guanzhong basin during daytime, which is not favorable for the transport of biogenic emissions from the Qin Ling. Although the
$\mathrm{O}_{3}$ level enhanced by biogenic emissions is not significant in Xi' an and surrounding areas, the high reactivity of biogenic VOCs, such as isoprene and monoterpenes, will play an increasingly important role in $\mathrm{O}_{3}$ formation when the anthropogenic VOCs are decreased as a result of $\mathrm{O}_{3}$ control measures.

We have further used the sensitivity studies to evaluate the contribution of anthropogenic emissions from industrial, residential, and transportation sources to $\mathrm{O}_{3}$ production. The industrial emissions contribute more than $70 \%$ of the anthropogenic VOCs and play the most important role in the $\mathrm{O}_{3}$ formation in $\mathrm{Xi}$ ' an and surrounding areas during daytime, compared to residential and transportation emissions. On average, the near-surface $\mathrm{O}_{3}$ contribution from industrial emissions is about $10-30 \mu \mathrm{g} \mathrm{m}^{3}$ in the afternoon and exceeds $20 \mu \mathrm{g} \mathrm{m}^{-3}$ during $\mathrm{O}_{3}$ peak time (Fig. 19b). Transportation emissions contribute about 10 to $20 \mu \mathrm{g} \mathrm{m}^{-3}$ ozone in the afternoon, while residential emissions contribute less than $10 \mu \mathrm{g} \mathrm{m}^{-3} \mathrm{O}_{3}$.

Sensitivity studies have shown that there is no single anthropogenic ozone precursor emission source that dominates the $\mathrm{O}_{3}$ level in $\mathrm{Xi}$ ' an and surrounding areas. The simulation without the most important industrial source still predicts high near-surface $\mathrm{O}_{3}$ concentrations in Xi' an and surrounding areas (Fig. 19a). The $\mathrm{O}_{3}$ production regime in $\mathrm{Xi}^{\prime}$ an and surrounding areas varies from $\mathrm{NO}_{x}$ - to VOC-sensitive chemistry, constituting one of the possible reasons for the insensitivity of $\mathrm{O}_{3}$ concentration to the emission change. Addi- 

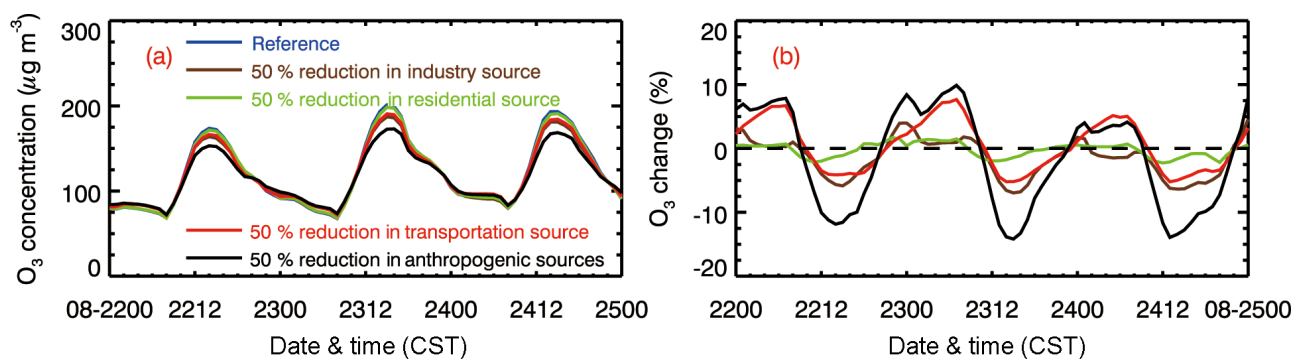

Figure 20. Diurnal profiles of (a) $\mathrm{O}_{3}$ concentrations and (b) $\mathrm{O}_{3}$ changes averaged in Xi' an and surrounding areas caused by a $50 \%$ reduction in various anthropogenic sources from 22 to 24 August 2013. Blue line: the reference simulation; brown line: the simulation with a $50 \%$ reduction in industry emissions; green line: the simulation with a $50 \%$ reduction in residential emissions; red line: the simulation with a $50 \%$ reduction in transportation emissions; the black line: the simulation with a $50 \%$ reduction in all anthropogenic emissions.

Table 4. Occurrence days of the defined $\mathrm{PM}_{2.5}$ and $\mathrm{O}_{3}$ exceedance levels during the summer of 2013.

\begin{tabular}{lcccccc}
\hline & Beijing & Tianjin & Shijiazhuang & Jinan & Taiyuan & Xi'an \\
\hline${ }^{1}$ Level I & 57 & 65 & 64 & 72 & 53 & 61 \\
${ }^{2}$ Level II & 33 & 41 & 43 & 41 & 28 & 20 \\
\hline
\end{tabular}

${ }^{1}$ Hourly $\mathrm{PM}_{2.5}$ and $\mathrm{O}_{3}$ concentrations exceeding 35 and $160 \mu \mathrm{g} \mathrm{m}{ }^{-3}$, respectively. ${ }^{2}$ Hourly $\mathrm{PM}_{2.5}$ and $\mathrm{O}_{3}$ concentrations exceeding 75 and $200 \mathrm{\mu g} \mathrm{m}^{-3}$, respectively. The original data are from China MEP.

tionally, in the case of high aerosol levels, aerosol effects on photolysis also compensate for the $\mathrm{O}_{3}$ decrease through enhancing photolysis frequencies due to a decrease in aerosol concentrations caused by the emission reduction. Although biogenic emission does not play a major role in the $\mathrm{O}_{3}$ formation in Xi' an and surrounding areas, it provides reactive a VOC precursor for $\mathrm{O}_{3}$ formation. Therefore, with high $\mathrm{O}_{3}$ and $\mathrm{PM}_{2.5}$ in Xi' an and surrounding areas, decreasing emissions from various anthropogenic sources alone cannot efficiently mitigate the $\mathrm{O}_{3}$ pollution. Sensitivity studies have been performed to further demonstrate the difficulties in devising $\mathrm{O}_{3}$ control strategies through decreasing anthropogenic emissions from industry, residential, transportation, and all anthropogenic sources by $50 \%$ in the WRF-Chem simulations. A $50 \%$ reduction in industrial emissions only resulted in less than a $7 \%$ decrease in $\mathrm{O}_{3}$ concentrations in $\mathrm{Xi}^{\prime}$ an and surrounding areas (Fig. 20). Even if all the anthropogenic emissions are reduced by $50 \%$, the decrease in $\mathrm{O}_{3}$ concentrations is not more than $14 \%$.

\section{Summary and conclusions}

In this study, a 3-day episode with high $\mathrm{O}_{3}$ and $\mathrm{PM}_{2.5}$ concentrations from 22 to 24 August 2013, is simulated using the WRF-Chem model to evaluate the $\mathrm{O}_{3}$ formation in Xi' an and surrounding areas. The WRF-Chem model generally performs well in simulating the surface temperature and relative humidity compared to the observations and also reasonably reproduces the observed temporal variations of the surface wind speed and direction. The convergence formed in Xi' an and surrounding areas is favorable for the accumulation of pollutants, leading to high concentrations of $\mathrm{O}_{3}$ and $\mathrm{PM}_{2.5}$. In general, the calculated spatial patterns and temporal variations of near-surface $\mathrm{O}_{3}$ and $\mathrm{PM}_{2.5}$ are consistent with the measurements at the ambient monitoring stations. The simulated daily mass concentrations of aerosol constituents, including sulfate, nitrate, ammonium, and elemental and organic carbon, are also in good agreement with the filter measurements. The simulated column-integrated AOD at $550 \mathrm{~nm}$ and SSA at $440 \mathrm{~nm}$ are compared to the available measurements from the surface site and satellite. The calculated AOD and SSA agree well with the measurements on 22 August, but the AOD and SSA simulations are biased considerably on 23 August, which is perhaps caused by underestimation of the relative humidity.

High aerosol levels significantly decrease the photolysis frequencies in Xi' an and surrounding areas. On average, the $J\left[\mathrm{NO}_{2}\right]$ at the ground surface is decreased by $30-70 \%$ in the early morning and late afternoon when the solar zenith angle is large, and even around noontime, the decrease of $J\left[\mathrm{NO}_{2}\right]$ is still significant, exceeding $20 \%$ on 23 and 24 August. The aerosol effect on photolysis decreases the $\mathrm{O}_{3}$ formation in the late morning and early afternoon remarkably, with an $\mathrm{O}_{3}$ reduction of more than $50 \mathrm{\mu g} \mathrm{m}^{-3}$ on average in Xi' an and surrounding areas. The significant aerosol effects on $\mathrm{O}_{3}$ formation complicate the design of $\mathrm{O}_{3}$ control strategies. If the $\mathrm{O}_{3}$ mitigation causes a reduction in aerosols directly and indirectly, the enhanced photolysis due to the aerosol decrease compensates for the $\mathrm{O}_{3}$ reduction. 
Sensitivity studies demonstrate that the $\mathrm{O}_{3}$ production regime in Xi' an and surrounding areas varies from $\mathrm{NO}_{x}$ - to VOC-sensitive chemistry, constituting a dilemma for $\mathrm{O}_{3}$ control strategies. Studies in northern China show that the BTH area is under a VOC-sensitive regime (Wang et al., 2006; Tang et al., 2012). Xue et al. (2014) also reports that $\mathrm{O}_{3}$ production is VOC-limited in both Shanghai and Guangzhou but $\mathrm{NO}_{x}$-limited in Lanzhou. The industrial emissions contribute the most to the $\mathrm{O}_{3}$ concentrations in $\mathrm{Xi}$ ' an and surrounding areas, but neither individual anthropogenic emission nor biogenic emissions play a dominant role in the $\mathrm{O}_{3}$ formation. Under the situation with high $\mathrm{O}_{3}$ and $\mathrm{PM}_{2.5}$ concentrations in $\mathrm{Xi}$ ' an and surrounding areas, mitigation of $\mathrm{O}_{3}$ pollution is challenging through decreasing emissions from various anthropogenic sources. A $50 \%$ reduction in all the anthropogenic emissions only decreases the near-surface $\mathrm{O}_{3}$ level by less than $14 \%$ on average in $\mathrm{Xi}^{\prime}$ an and surrounding areas.

Xi' an and surrounding areas, with a population of more than 10 million, are a representative region in the northwest of China, experiencing rapid industrialization and urbanization in recent years. Heavy haze or photochemical smog events frequently engulf the region, substantially impairing visibility and potentially causing severe health effects. Although the dispersion conditions have improved during summertime, the occurrence of heavy pollution events with both high $\mathrm{PM}_{2.5}$ and $\mathrm{O}_{3}$ levels is frequent in the region, exceeding China air quality standards (Table 1). We have defined two exceedance levels: Level I with hourly $\mathrm{PM}_{2.5}$ and $\mathrm{O}_{3}$ concentrations exceeding 35 and $160 \mu \mathrm{g} \mathrm{m}^{-3}$, respectively, and Level II with hourly $\mathrm{PM}_{2.5}$ and $\mathrm{O}_{3}$ concentrations exceeding 75 and $200 \mu \mathrm{g} \mathrm{m}^{-3}$, respectively. We have further analyzed the real-time hourly observations of $\mathrm{PM}_{2.5}$ and $\mathrm{O}_{3}$ concentrations in the afternoon in megacities or urban complexes of the northern part of China to explore the occurrence days of the defined exceedance levels during the summer of 2013 (Table 4). As shown in Table 4, in Tianjin, Shijiazhuang, and Jinan, the number of days of exceedance level II is more than 40 , that is, haze and photochemical smog events hit the three cities simultaneously on at least 40 days in the afternoon during the summer of 2013. Thus, the model results in the present study, from an episode with high concentrations of $\mathrm{O}_{3}$ and $\mathrm{PM}_{2.5}$ in Xi' an and surrounding areas, can potentially provide beneficial support for the design and implementation of emission control strategies in those cities in North China. The occurrence of high $\mathrm{O}_{3}$ levels with high $\mathrm{PM}_{2.5}$ concentrations constitutes a dilemma for the design of $\mathrm{O}_{3}$ control strategies. If the $\mathrm{O}_{3}$ mitigation approach decreases aerosols in the atmosphere directly or indirectly, the enhanced photolysis caused by aerosol reduction would compensate for the $\mathrm{O}_{3}$ loss. If the $\mathrm{PM}_{2.5}$ control strategy is implemented only, the $\mathrm{O}_{3}$ pollution situation will deteriorate. Since the release of the "Atmospheric Pollution Prevention and Control Action Plan" in 2013 (http://www.gov.cn/zwgk/2013-09/ 12/content_2486773.htm), a stringent $\mathrm{PM}_{2.5}$ control strat- egy has been implemented in China. The summertime $\mathrm{PM}_{2.5}$ concentration in the afternoon in $\mathrm{Xi}$ 'an has decreased from $48.5 \mu \mathrm{g} \mathrm{m}^{-3}$ in 2013 to $38.8 \mu \mathrm{g} \mathrm{m}^{-3}$ in 2014 ; however, the $\mathrm{O}_{3}$ concentration has increased from $104.6 \mu \mathrm{g} \mathrm{m}^{-3}$ in 2013 to $114.7 \mu \mathrm{g} \mathrm{m}^{-3}$ in 2014 . The same trend is also found in the cities of BTH: the $\mathrm{PM}_{2.5}$ concentration has decreased from $71.5 \mu \mathrm{g} \mathrm{m}^{-3}$ in 2013 to $57.4 \mu \mathrm{g} \mathrm{m}^{-3}$ in 2014 , while the $\mathrm{O}_{3}$ concentration has increased from $125.8 \mathrm{\mu g} \mathrm{m}^{-3}$ in 2013 to $139.1 \mu \mathrm{g} \mathrm{m}^{-3}$ in 2014. Therefore, the decrease in the $\mathrm{PM}_{2.5}$ level might enhance $\mathrm{O}_{3}$ production, which is consistent with the results in the present study.

It is worth noting that, although the WRF-Chem model generally performs well in the simulations of the gas-phase species and aerosols compared to measurements, it still sometimes underestimates or overestimates the observations. One of the possible reasons for the discrepancies between simulations and observations is the uncertainty of the emission inventory, which has undergone noticeable changes due to rapid urbanization and industrialization and implementation of air pollution control strategies in the Guanzhong basin since the base year (2010) when the emission inventory was developed; thus, the emission inventory will need updating in future studies. The model results are also sensitive to the meteorological field uncertainty, e.g., the biases of modeled wind fields significantly impact the simulations of the variation and pattern of the gas-phase species and aerosols in the early morning on 23 August and in the afternoon on $24 \mathrm{Au}-$ gust. Studies need to be conducted to further improve the meteorological field simulations in $\mathrm{Xi}$ ' an and surrounding areas for the assessment of $\mathrm{O}_{3}$ formation.

\section{Data availability}

The real-time $\mathrm{O}_{3}, \mathrm{NO}_{2}$, and $\mathrm{PM}_{2.5}$ are accessible to the public on the website http://106.37.208.233:20035/. One can also access the historic profile of observed ambient pollutants through visiting http://www.aqistudy.cn/.

Acknowledgements. This work was supported by the National Natural Science Foundation of China (no. 41275153) and the "Strategic Priority Research Program" of the Chinese Academy of Sciences (Grant no. XDB05060500). Guohui Li was also supported by the "Hundred Talents Program" of the Chinese Academy of Sciences. Naifang Bei was supported by the National Natural Science Foundation of China (no. 41275101).

Edited by: A. Engel

\section{References}

Bei, N., de Foy, B., Lei, W., Zavala, M., and Molina, L. T.: Using 3DVAR data assimilation system to improve ozone simulations in the Mexico City basin, Atmos. Chem. Phys., 8, 7353-7366, doi:10.5194/acp-8-7353-2008, 2008. 
Bei, N., Lei, W., Zavala, M., and Molina, L. T.: Ozone predictabilities due to meteorological uncertainties in the Mexico City basin using ensemble forecasts, Atmos. Chem. Phys., 10, 6295-6309, doi:10.5194/acp-10-6295-2010, 2010.

Bei, N., Li, G., and Molina, L. T.: Uncertainties in SOA simulations due to meteorological uncertainties in Mexico City during MILAGRO-2006 field campaign, Atmos. Chem. Phys., 12, 11295-11308, doi:10.5194/acp-12-11295-2012, 2012.

Binkowski, F. S. and Roselle, S. J.: Models-3 Community Multiscale Air Quality (CMAQ) model aerosol component 1. Model description, J. Geophys. Res., 108, 4183, doi:10.1029/2001JD001409, 2003.

Brasseur, G. P., Orlando, J. J., and Tyndall, G. S.: Atmospheric chemistry and global change, Oxford University Press, Cambridge, USA, 654 pp., 1999.

Cao, J., Xu, H., Xu, Q., Chen, B., and Kan, H.: Fine particulate matter constituents and cardiopulmonary mortality in a heavily polluted Chinese city, Environ. Health Persp., 120, 373-378, 2012.

Cao, J. J., Wu, F., Chow, J. C., Lee, S. C., Li, Y., Chen, S. W., An, Z. S., Fung, K. K., Watson, J. G., Zhu, C. S., and Liu, S. X.: Characterization and source apportionment of atmospheric organic and elemental carbon during fall and winter of 2003 in Xi' an, China, Atmos. Chem. Phys., 5, 3127-3137, doi:10.5194/acp-53127-2005, 2005.

Carlton, A. G., Bhave, P. V., Napelenok, S. L., Edney, E. O., Sarwar, G., Pinder, R. W., Pouliot, G. A., and Houyoux, M.: Model Representation of Secondary Organic Aerosol in CMAQv4.7, Environ. Sci. Technol., 44, 8553-8560, doi:10.1021/es100636q, 2010.

Castro, T., Madronich, S., Rivale, S., Muhlia, A., and Mar B.: The influence of aerosols on photochemical smog in Mexico City, Atmos. Environ., 35, 1765-1772, 2001.

Chen, F. and Dudhia, J.: Coupling an advanced land-surface/hydrology model with the Penn State/NCARMM5modelingsystem. Part I: Model description and implementation, Mon. Weather Rev., 129, 569-585, 2001.

Chen, F., Kusaka, H., Bornstein, R., Ching, J., Grimmond, C. S. B., Grossman-Clarke, S., Loridan, T., Manning, K. W., Martilli, A., Miao, S., Sailor, D., Salamanca, F. P., Taha, H., Tewari, M., Wang, X., Wyszogrodzki, A. A., and Zhang, C.: The integrated WRF/urban modelling system: development, evaluation, and applications to urban environmental problems, Int. J. Climatol., 31, 273-288, doi:10.1002/joc.2158, 2011.

Cheng, H. R., Guo, H., Saunders, S. M., Lam, S. H. M., Jiang, F., Wang, X. M., Simpson, I. J., Blake, D. R., Louie, P. K. K., and Wang, T. J.: Assessing photochemical ozone formation in the Pearl River Delta with a photochemical trajectory model, Atmos. Environ., 44, 4199-4208, 2010.

Chou, M.-D. and Suarez, M. J.: An efficient thermal infrared radiation parameterization for use in general circulation models, NASA Tech. Memo. 104606, 3, 85 pp., 1994.

Cooper, O. R., Parrish, D. D., Ziemke, J., Balashov, N. V., Cupeiro, M., Galbally, I. E., Gilge, S., Horowitz, L., Jensen, N. R., Lamarque, J. F., Naik, V., Oltmans, S. J., Schwab, J., Shindell, D. T., Thompson, A. M., Thouret, V., Wang, Y., and Zbinden, R. M.: Global distribution and trends of tropospheric ozone: An observation-based review, Elem. Sci. Anth., 2, 000029, doi:10.12952/journal.elementa.000029, 2014.
De Smedt, I., Stavrakou, T., Müller, J. F., van der A, R. J., and Van Roozendael, M.: Trend detection in satellite observations of formaldehyde tropospheric columns, Geophys. Res. Lett., 37, L18808, doi:10.1029/2010GL044245, 2010.

Geng, F., Tie, X., Guenther, A., Li, G., Cao, J., and Harley, P.: Effect of isoprene emissions from major forests on ozone formation in the city of Shanghai, China, Atmos. Chem. Phys., 11, 1044910459, doi:10.5194/acp-11-10449-2011, 2011.

Geng, F. H., Qiang, Z., Tie, X., Huang, M., Ma, X., Deng, Z., Quan, J., and Zhao, C.: Aircraft measurements of $\mathrm{O}_{3}, \mathrm{NO}_{x}, \mathrm{CO}$, VOCs, and $\mathrm{SO}_{2}$ in the Yangtze River Delta region, Atmos. Environ., 43, 584-593, 2009.

Guenther, A., Karl, T., Harley, P., Wiedinmyer, C., Palmer, P. I., and Geron, C.: Estimates of global terrestrial isoprene emissions using MEGAN (Model of Emissions of Gases and Aerosols from Nature), Atmos. Chem. Phys., 6, 3181-3210, doi:10.5194/acp-63181-2006, 2006.

Grell, G. A., Peckham, S. E., Schmitz, R., McKeen, S. A., Wilczak, J., and Eder, B.: Fully coupled "online" chemistry within the WRF model, Atmos. Environ., 39, 6957-6975, 2005.

Horowitz, L. W., Walters, S., Mauzerall, D. L., Emmons, L. K., Rasch, P. J., Granier, C., Tie, X., Lamarque, J.-F., Schultz, M G., Tyndall, G. S., Orlando, J. J., and Brasseur, G. P.: A global simulation of tropospheric ozone and related tracers: Description and evaluation of MOZART, version 2, J. Geophys. Res., 108, 4784, doi:10.1029/2002JD002853, 2003.

Ianniello, A., Spataro, F., Esposito, G., Allegrini, I., Hu, M., and Zhu, T.: Chemical characteristics of inorganic ammonium salts in $\mathrm{PM}_{2.5}$ in the atmosphere of Beijing (China), Atmos. Chem. Phys., 11, 10803-10822, doi:10.5194/acp-11-10803-2011, 2011.

Jacobson, M. Z.: Studying the effects of aerosols on vertical photolysis rate coefficient and temperature profiles over an urban airshed, J. Geophys. Res., 103, 10593-10604, 1998.

Janjic, Z. I.: Nonsingular implementation of the Mellor-Yamada Level 2.5 Scheme in the NCEP Meso model, NCEP Office Note No. 437, 61 pp., 2002.

Lee, S.-H., Kim, S.-W., Angevine, W. M., Bianco, L., McKeen, S. A., Senff, C. J., Trainer, M., Tucker, S. C., and Zamora, R. J.: Evaluation of urban surface parameterizations in the WRF model using measurements during the Texas Air Quality Study 2006 field campaign, Atmos. Chem. Phys., 11, 2127-2143, doi:10.5194/acp-11-2127-2011, 2011.

Li, G., Zhang, R., Fan, J., and Tie, X.: Impacts of black carbon aerosol on photolysis and ozone, J. Geophys. Res., 110, D23206, doi:10.1029/2005JD005898, 2005.

Li, G., Zhang, R., Fan, J., and Tie, X.: Impacts of biogenic emissions on photochemical ozone production in Houston, Texas, J. Geophys. Res., 112, D10309, doi:10.1029/2006JD007924, 2007.

Li, G., Lei, W., Zavala, M., Volkamer, R., Dusanter, S., Stevens, P., and Molina, L. T.: Impacts of HONO sources on the photochemistry in Mexico City during the MCMA-2006/MILAGO Campaign, Atmos. Chem. Phys., 10, 6551-6567, doi:10.5194/acp-106551-2010, 2010.

Li, G., Zavala, M., Lei, W., Tsimpidi, A. P., Karydis, V. A., Pandis, S. N., Canagaratna, M. R., and Molina, L. T.: Simulations of organic aerosol concentrations in Mexico City using the WRFCHEM model during the MCMA-2006/MILAGRO campaign, Atmos. Chem. Phys., 11, 3789-3809, doi:10.5194/acp-11-37892011, 2011a. 
Li, G., Bei, N., Tie, X., and Molina, L. T.: Aerosol effects on the photochemistry in Mexico City during MCMA2006/MILAGRO campaign, Atmos. Chem. Phys., 11, 51695182, doi:10.5194/acp-11-5169-2011, 2011b.

Li, G., Lei, W., Bei, N., and Molina, L. T.: Contribution of garbage burning to chloride and $\mathrm{PM}_{2.5}$ in Mexico City, Atmos. Chem. Phys., 12, 8751-8761, doi:10.5194/acp-12-8751-2012, 2012.

Li, Y., Lau, A. K. H., Fung, J. C. H., Zheng, J., and Liu, S.: Importance of NOx control for peak ozone reduction in the Pearl River Delta region, J. Geophys. Res., 118, 9428-9443, doi:10.1002/jgrd.50659, 2013.

Lin, W., Xu, X., Zhang, X., and Tang, J.: Contributions of pollutants from North China Plain to surface ozone at the Shangdianzi GAW Station, Atmos. Chem. Phys., 8, 5889-5898, doi:10.5194/acp-8-5889-2008, 2008.

Lin Y.-L., Farley, R. D., and Orville, H. D.:, Bulk parameterization of the snow field in a cloud model, J. Appl. Meteorol., 22, 10651092, 1983.

Lu, Z., Zhang, Q., and Streets, D. G.: Sulfur dioxide and primary carbonaceous aerosol emissions in China and India, 1996-2010, Atmos. Chem. Phys., 11, 9839-9864, doi:10.5194/acp-11-98392011, 2011.

Ministry of Environmental Protection, China (China MEP): Air Quality Observation Real-time Release Platform of MEP Data Center, http://106.37.208.233:20035/, 2013.

Ministry of Environmental Protection, China (China MEP): Online Monitoring and Analysis Platform of China Air Quality, http: //www.aqistudy.cn/, 2013.

Mlawer, E. J., Taubman, S. J., Brown, P. D., Iacono, M. J., and Clough, S. A.: Radiative transfer for inhomogeneous atmosphere: RRTM, a validated correlated-k model for the long-wave J. Geophys. Res., 102, 16663-16682, 1997.

Seinfeld, J. H. and Pandis, S. N.: Atmospheric chemistry and physics: from air pollution to climate Change, 2nd Edn., John Wiley \& Sons, Inc., New York, USA, 1326 pp., 2006.

Shen, Z., Cao, J., Arimoto, R., Han, Z., Zhang, R., Han, Y., Liu, S., Okuda, T., Nakao, S., and Tanaka, S.: Ionic composition of TSP and $\mathrm{PM}_{2.5}$ during dust storms and air pollution episodes at Xi'an, China, Atmos. Environ., 43, 2911-2918, 2009.

Shen, Z. X., Arimoto, R., Okuda, T., Cao, J. J., Zhang, R. J., Li, X. X., Du, N., Nakao, S., and Tanaka, S.: Seasonal variations and evidence for the effectiveness of pollution controls on watersoluble inorganic species in TSP and $\mathrm{PM}_{2.5}$ from Xi'an, China, J. Air Waste Manage., 58, 1560-1570, 2008.

Shrivastava, M. K., Lane, T. E., Donahue, N. M., Pandis, S. N., and Robinson, A. L.: Effects of gas-particle partitioning and aging of primary emissions on urban and regional organic aerosol concentrations, J. Geophys. Res., 113, D18301, doi:10.1029/2007JD009735, 2008.

Sillman, S.: The use of $\mathrm{NO}_{y}, \mathrm{H}_{2} \mathrm{O}_{2}$ and $\mathrm{HNO}_{3}$ as indicators for $\mathrm{O}_{3}-$ $\mathrm{NO}_{x}$-VOC sensitivity in urban locations, J. Geophys. Res., 100, 14175-14188, 1995.

Skamarock, W. C.: Evaluating Mesoscale NWP models using kinetic energy spectra, Mon. Weather Rev., 132, 3019-3032, 2004.

Solmon, F., Sarrat, C., Serça, D., Tulet, P., and Rosset, R.: Isoprene and monoterpenes biogenic emissions in France: modeling and impact during a regional pollution episode, Atmos. Environ., 38, 3853-3865, doi:10.1016/j.atmosenv.2004.03.054, 2004.
Stockwell, W. R. and Goliff, W. S.: Measurement of actinic flux and the calculation of photolysis rate parameters for the Central California Ozone Study, Atmos. Environ., 38, 5169-5177, 2004.

Su, X., Cao, J., Li, Z., Lin, M., and Wang, G.: Columnintegrated aerosol optical properties during summer and autumn of 2012 in Xi'an, China, Aerosol Air Qual. Res., 14, 850-861, doi:10.4209/aaqr.2013.03.0093, 2014.

Tang, G., Li, X., Wang, Y., Xin, J., and Ren, X.: Surface ozone trend details and interpretations in Beijing, 2001-2006, Atmos. Chem. Phys., 9, 8813-8823, doi:10.5194/acp-9-8813-2009, 2009.

Tang, G., Wang, Y., Li, X., Ji, D., Hsu, S., and Gao, X.: Spatialtemporal variations in surface ozone in Northern China as observed during 2009-2010 and possible implications for future air quality control strategies, Atmos. Chem. Phys., 12, 2757-2776, doi:10.5194/acp-12-2757-2012, 2012.

Tie, X., Madronich, S., Walters, S., Zhang, R., Rasch, P., and Collins, W.: Effect of clouds on photolysis and oxidants in the troposphere, J. Geophys. Res., 108, 4642, doi:10.1029/2003JD003659, 2003.

Tie, X., Geng, F. H., Peng, L., Gao, W., and Zhao, C. S.: Measurement and modeling of $\mathrm{O}_{3}$ variability in Shanghai, China; Application of the WRF-CHEM model, Atmos. Environ., 43, 42894302, 2009.

Tie, X., Geng, F., Guenther, A., Cao, J., Greenberg, J., Zhang, R., Apel, E., Li, G., Weinheimer, A., Chen, J., and Cai, C.: Megacity impacts on regional ozone formation: observations and WRFChem modeling for the MIRAGE-Shanghai field campaign, Atmos. Chem. Phys., 13, 5655-5669, doi:10.5194/acp-13-56552013, 2013.

Tsimpidi, A. P., Karydis, V. A., Zavala, M., Lei, W., Molina, L., Ulbrich, I. M., Jimenez, J. L., and Pandis, S. N.: Evaluation of the volatility basis-set approach for the simulation of organic aerosol formation in the Mexico City metropolitan area, Atmos. Chem. Phys., 10, 525-546, doi:10.5194/acp-10-525-2010, 2010.

Volkamer, R., San Martini, F., Molina, L. T., Salcedo, D., Jimenez, J. L., and Molina, M. J.: A Missing Sink for Gas-Phase Glyoxal in Mexico City: Formation of Secondary Organic Aerosol, Geophys. Res. Lett., 34, L19807, doi:10.1029/2007GL030752, 2007.

Wang, T., Ding, A., Gao, J., and Wu, W. S.:, Strong ozone production in urban plumes from Beijing, China, Geophys. Res. Lett. 33, L21806, doi:10.1029/2006GL027689, 2006.

Wang, T., Wei, X. L., Ding, A. J., Poon, C. N., Lam, K. S., Li, Y. S., Chan, L. Y., and Anson, M.: Increasing surface ozone concentrations in the background atmosphere of Southern China, 19942007, Atmos. Chem. Phys., 9, 6217-6227, doi:10.5194/acp-96217-2009, 2009.

Wang, X., Zhang, Y., Hu, Y., Zhou, W., Zeng, L., Hu, M., Cohan, D. S., and Russell, A. G.: Decoupled direct sensitivity analysis of regional ozone pollution over the Pearl River Delta during the PRIDE-PRD2004 campaign, Atmos. Environ., 45, 4941-4949, doi:10.1016/j.atmosenv.2011.06.006, 2011.

Wang, X., Shen, Z., Cao, J., Zhang, L., Liu, L., Li, J., Liu, L., and Sun, Y.: Characteristics of surface ozone at an urban site of Xi' an in Northwest China, J. Environ. Monitor., 14, 116-125, 2012.

Wang, Y., Zhang, Q., Jiang, J., Zhou, W., Wang, B., He, K., Duan, F., Zhang, Q., Philip, S., and Xie, Y.: Enhanced sulfate formation during China's severe winter haze episode in January 2013 missing from current models, J. Geophys. Res., 119, 10425-10440, doi:10.1002/2013JD021426, 2014. 
Wesely, M. L.: Parameterization of surface resistances to gaseous dry deposition in regional-scale numerical models, Atmos. Environ., 23, 1293-1304, doi:10.1016/0004-6981(89)90153-4, 1989.

Xu, J., Ma, J. Z., Zhang, X. L., Xu, X. B., Xu, X. F., Lin, W. L., Wang, Y., Meng, W., and Ma, Z. Q.: Measurements of ozone and its precursors in Beijing during summertime: impact of urban plumes on ozone pollution in downwind rural areas, Atmos. Chem. Phys., 11, 12241-12252, doi:10.5194/acp11-12241-2011, 2011.

Xue, L. K., Wang, T., Gao, J., Ding, A. J., Zhou, X. H., Blake, D. R., Wang, X. F., Saunders, S. M., Fan, S. J., Zuo, H. C., Zhang, Q. Z., and Wang, W. X.: Ground-level ozone in four Chinese cities: precursors, regional transport and heterogeneous processes, Atmos. Chem. Phys., 14, 13175-13188, doi:10.5194/acp14-13175-2014, 2014.

Zhao, J., Levitt, N. P., Zhang, R. Y., and Chen, J. M.: Heterogeneous reactions of methylglyoxal in acidic media: implications for secondary organic aerosol formation, Environ. Sci. Technol., 40, 7682-7687, 2006.
Zhang, Q., Streets, D. G., Carmichael, G. R., He, K. B., Huo, H., Kannari, A., Klimont, Z., Park, I. S., Reddy, S., Fu, J. S., Chen, D., Duan, L., Lei, Y., Wang, L. T., and Yao, Z. L.: Asian emissions in 2006 for the NASA INTEX-B mission, Atmos. Chem. Phys., 9, 5131-5153, doi:10.5194/acp-9-5131-2009, 2009.

Zhang, Y. H., Su, H., Zhong, L. J., Cheng, Y. F., Zeng, L. M., Wang, X. S., Xiang, Y. R., Wang, J. L., Gao, D. F., and Shao, M.: Regional ozone pollution and observation-based approach for analyzing ozone-precursor relationship during the PRIDEPRD2004 campaign, Atmos. Environ., 42, 6203-6218, 2008.

Zhou, J., Ito, K., Lall, R., Lippmann, M., and Thurston, G.: Timeseries analysis of mortality effects of fine particulate matter components in Detroit and Seattle, Environ. Health Persp., 119, 461466, 2011. 